\title{
Preparation and Catalytic Properties of Various Oxides and Mesoporous Materials Containing Niobium and Sulfate Ions, in the Etherification Reaction of 2-Naphtol
}

\author{
Alaa H. Hussein",2,3, Hiba Nahas',2, Mohamad Jahjah",2, Mourtada Srour1,2, Rabih Jahjah1,2, \\ Nicolas Duget ${ }^{3}$, Marc Lemaire ${ }^{3}$, Daoud Naoufal1,2* \\ ${ }^{1}$ Laboratoire de Chimie de Coordination Inorganique et Organométallique (LCIO), Université Libanaise, Faculté des Sciences I, \\ Hadath, Liban \\ ${ }^{2}$ Ecole Doctorale des Sciences et Technologie EDST, PRASE, Université Libanaise, Hadath, Liban \\ ${ }^{3}$ Institut de Chimie et Biochimie Moléculaires et Supramoléculaires (ICBMS), UMR 5246 CNRS, Université Claude Bernard Lyon \\ 1, Villeurbanne, France \\ Email: ^dnaoufal@ul.edu.lb
}

How to cite this paper: Hussein, A.H., Nahas, H., Jahjah, M., Srour, M., Jahjah, R., Duget, N., Lemaire, M. and Naoufal, D. (2018) Preparation and Catalytic Properties of Various Oxides and Mesoporous Materials Containing Niobium and Sulfate Ions, in the Etherification Reaction of 2-Naphtol. International Journal of Organic Chemistry, 8, 16-40.

https://doi.org/10.4236/ijoc.2018.81002

Received: December 11, 2017

Accepted: January 22, 2018

Published: January 25, 2018

Copyright ( 92018 by authors and Scientific Research Publishing Inc. This work is licensed under the Creative Commons Attribution International License (CC BY 4.0).

http://creativecommons.org/licenses/by/4.0/

\section{(c) (i) Open Access}

\begin{abstract}
Several types of solid acid catalysts were prepared based on oxides like $\left(\mathrm{ZrO}_{2}\right.$, $\mathrm{TiO}_{2}, \mathrm{HfO}_{2}, \mathrm{MCM}-41$ and SBA-15), using two main preparation methods: the precipitation and the sol-gel methods. Each catalyst was subjected to two types of impregnations: sulfate ions using sulfuric acid as precursor and niobium using niobium oxalate as precursor. These prepared catalysts were tested in the etherification reaction of 2-naphtol, where the catalysts showed both acidic and redox properties. The acidic character was manifested through the formation of 2-butoxynaphtalene (with moderate yields) when oxide is sulfated, and the redox character (when impregnated with niobium) manifested through the formation of the interesting product 2-ethylnaphtofuran (with low yields) and other products that were a result of oxidative coupling of two 2-naphtol molecules (binol and acetal of binol). However despite the effort, several attempts to increase the yield of 2-ethylnaphtofuran did not work. All products prepared were obtained in pure form and characterized by ${ }^{1} \mathrm{H}$ and ${ }^{13} \mathrm{C}$ NMR, GC and MS.
\end{abstract}

\section{Keywords}

Sulfated Oxides, Mesoporous Materials, Niobium, Solid Acid Catalysis, Etherification 


\section{Introduction}

Tightening environmental legislation is driving the fine and specialty chemicals industries to consider alternative processes that avoid the use of conventional mineral acids. Research nowadays is focused on the use of heterogeneous acid catalysts. By using these solid acid catalysts, chemical processes become more productive and more environmentally friendly. In fact, they are being used in many industrial chemical processes from the largest chemical process of catalytic cracking in petroleum refining to the synthesis of various fine chemicals [1] [2], the preparation of active and selective heterogeneous acid catalysts is a challenge.

The chemistry of ethers are of great interest due to the vast presence of the C-O-C group in different domains of chemistry: pharmaceutical, agrochemicals and the petroleum industry. In our work, the main focus was on the various ethers of 2-naphthol, which are commercially attractive due to their extensive applications in the fine chemical industry.

The current practice for the manufacture of these ethers is based on Williamson type synthesis using base and toxic alkyl halides [3] [4]. More recently, homogeneous acid-catalyzed reactions were also described [5]. Thus, studies in the etherification of 2-naphthol with different alcohols in the presence of solid acid catalysts appear to be relevant having both academic and industrial context. In our work, several types of known solid acid catalysts were prepared based on oxides like $\left(\mathrm{ZrO}_{2}, \mathrm{TiO}_{2}, \mathrm{HfO}_{2}, \mathrm{MCM}-41\right.$ and SBA-15), using two preparation methods: the precipitation and the sol-gel methods. Each catalyst received two types of impregnations: sulfate ions and niobium using sulfuric acid and niobium oxalate as precursors respectively. We chose these types of impregnations since both sulfate and niobium doping are reported to induce strong acidity to the oxides on which they are impregnated. These prepared catalysts were first screen tested in the etherification reaction of 2-naphtol with butanol to determine which has the highest acidity by comparing butoxynaphtalene (2) yields since the reaction of aromatic ether formation requires strong acids, where the catalyst that gave the highest yield of butoxynaphtalene would be the one with high acidity. During these tests, both acidic and redox properties appeared which will be discussed later. The optimization of the reaction conditions (time, temperature and catalyst loading) for this reaction will be discussed and the detailed preparation methods for each catalyst will be given.

\section{Experimental}

\subsection{Materials and Equipment}

Chemicals were supplied by Sigma-Aldrich, Fluka, Lancaster, Acros Organics, UNI-chem, Strem chemicals, VWR and Alfa Aesar. All products were used as received without further purification. NMR spectra were acquired on Bruker 300 spectrometer $\left({ }^{1} \mathrm{H}, 300 \mathrm{MHz} ;{ }^{13} \mathrm{C}, 75 \mathrm{MHz}\right)$ at $293 \mathrm{~K}$. Melting points were meas- 
ured using a Kofler Heizbank apparatus and noted in ${ }^{\circ} \mathrm{C}$. A muffle furnace (MF-120) was used to conduct the calcinations of all our catalysts under static air conditions. After drying, the materials were powdered, calcined and finally sealed in an ampoule until use. Before each reaction, the catalyst was heated at $200^{\circ} \mathrm{C}$ under vacuum for $3 \mathrm{~h}$ (done in a vacuum oven).

\subsection{Surface Acidity Determination Method}

The acidity of all the prepared solid acid catalysts were measured by previously reported titrimetric method [6]. This method insured the detection of the total acid content. For this, $0.02 \mathrm{~g}$ of the solid catalyst were added to $10 \mathrm{~mL}$ of $0.01 \mathrm{M}$ $\mathrm{NaOH}$ solution and stirred for $3 \mathrm{~h}$. Then it was filtered without washing and titrated with $0.01 \mathrm{M} \mathrm{HCl}$ using phenolphthalein as indicator. The consumed amount of $\mathrm{NaOH}$ was measured, from this calculated amount, the total acidic sites of the catalyst were calculated. The acidity was reported as $\mathrm{mmol}$ of $\mathrm{H}^{+}$per $\mathrm{g}$ of catalyst. The results of these measurements are listed in tables for each set of catalysts.

\subsection{Catalysts Preparations}

Several solid acid catalysts were prepared: microporous oxides $\left(\mathrm{ZrO}_{2}, \mathrm{TiO}_{2}\right.$, $\mathrm{HfO}_{2}$ ) and siliceous mesoporous materials (MCM-41 and SBA-15). The preparations of these solids were taken from known published methods in the literature [7]-[13].

\subsubsection{Zirconium Oxide Catalysts}

To prepare the zirconium catalysts using zirconium oxychloride as precursor, two general methods were used: the first was the precipitation method followed by impregnation (sulfate or niobium doping). The second was the sol-gel method based on using Zirconium n-propoxide as precursor. This method was done in two different synthesis mediums: acidic and basic. The idea behind all these variations of preparation methods was to obtain a wide variety of zirconium catalysts that were either in-situ or post sulfated plus niobium impregnated.

\section{1) Zirconium Catalysts Prepared by the Precipitation Method [7]}

$20 \mathrm{~g}$ of zirconium oxychloride $\left(\mathrm{ZrOCl}_{2} \cdot 8 \mathrm{H}_{2} \mathrm{O}\right)$ were dissolved in $200 \mathrm{~mL}$ of distilled water. Aqueous Ammonia solution $\left(\mathrm{NH}_{3(\mathrm{aq})} 35 \%\right)$ was added drop wise into solution with stirring until the mixture reached a $\mathrm{pH}$ value of 9 .Then the system was left for $24 \mathrm{~h}$ without stirring. The reaction mixture was filtered then washed with distilled water until no chloride ions could be detected (confirmed with $0.5 \mathrm{M} \mathrm{AgNO}_{3}$ solution). The solid obtained was dried at $100^{\circ} \mathrm{C}$ for $24 \mathrm{~h}$.

The obtained dried hydroxide was the subjected to three separate treatments; It was directly calcined at $650^{\circ} \mathrm{C}$ for $4 \mathrm{~h}$ in air to obtain the pure zirconium oxide $\mathrm{ZrO}_{2}$. In the second treatment it was impregnated with $0.5 \mathrm{M} \mathrm{H}_{2} \mathrm{SO}_{4}$ solution (15 $\mathrm{mL} \mathrm{H}_{2} \mathrm{SO}_{4}$ per $1 \mathrm{~g}$ of $\mathrm{Zr}(\mathrm{OH})_{4}$ ) under constant stirring for $24 \mathrm{~h}$. The solution was filtered and the residue was dried at $100^{\circ} \mathrm{C}$ for $24 \mathrm{~h}$ before calcinations in air at 
$650^{\circ} \mathrm{C}$ for $3 \mathrm{~h}$. The third treatment was the impregnation of the zirconium oxide with niobium using as precursor niobium oxalate $\left(\mathrm{C}_{10} \mathrm{H}_{5} \mathrm{NbO}_{20} \cdot \mathrm{xH}_{2} \mathrm{O}\right)$. The impregnation was carried out on the calcined $\mathrm{ZrO}_{2}$, by using an aqueous solution of niobium oxalate in $0.1 \mathrm{M}$ oxalic acid solution to obtain niobium weight percentages in the resulting catalysts of $3 \%$ and $5 \%$. The solids were then dried at $100^{\circ} \mathrm{C}$ for $24 \mathrm{~h}$ and calcined in air at $650^{\circ} \mathrm{C}$ for $4 \mathrm{~h}$ to finally yield the $\mathrm{ZrO}_{2} / \mathrm{Nb}$.

The loading of niobium on each of the impregnated zirconium oxides is calculated theoretically, and was not determined experimentally. The formula used to calculate the quantity of niobium oxalate that should be dissolved in the $0.1 \mathrm{M}$ oxalic acid solution is:

$$
m_{1}=M_{1} * \frac{m_{2}}{M_{2}}
$$

$m_{1}$ : mass of niobium oxalate;

$M_{1}$ : molecular weight of niobium oxalate;

$m_{2}$ : mass of niobium required to obtain a specific loading on a chosen oxide support;

$M_{2}$ : molar mass of niobium.

A full list of all zirconium oxide catalysts prepared by the precipitation method is shown in Table 1.

The optimal loadings of sulfate ions (0.5 - 1 M) and niobium (3\% - 5\%) dopings used on various oxides $\left(\mathrm{ZrO}_{2}, \mathrm{TiO}_{2}, \mathrm{HfO}_{2}, \mathrm{MCM}-41\right.$ and SBA-15) were chosen as seen in Table 1 after an optimization study that we conducted, to determine the optimal loading for each type of impregnation that gave the highest yields and the highest surface acidity. It turns out that no significant increase in yield or surface acidity were observed while increasing sulfuric acid concentration above $1 \mathrm{M}$ or niobium loadings above 5\% during impregnation step.

\section{2) Zirconium Catalysts Prepared by the Sol-Gel Method}

Sulfated zirconia samples were prepared by the one step as well as the two-step sol-gel technique. In the one step method (acid medium), addition of sulfuric acid was done directly in the synthesis mixture, which yielded the in-situ sulfated zirconia. In the two-steps procedure, it was done in alkaline medium with aqueous ammonia, then followed by sulfating with $\mathrm{H}_{2} \mathrm{SO}_{4}$ in the second step.

Table 1. Zirconium catalysts prepared by precipitation method.

\begin{tabular}{ccc}
$\begin{array}{c}\text { Catalyst } \\
\text { code }\end{array}$ & $\begin{array}{c}\text { Catalyst } \\
\text { composition }\end{array}$ & Precursor \\
\hline $\mathrm{ALH} 1$ & $\mathrm{ZrO}_{2}$ & $\mathrm{ZrOCl}_{2} \cdot 8 \mathrm{H}_{2} \mathrm{O}$ \\
$\mathrm{ALH} 2$ & $\mathrm{ZrO}_{2} / \mathrm{SO}_{4}^{2-}(0.5 \mathrm{M})$ & $\mathrm{ZrOCl}_{2} \cdot 8 \mathrm{H}_{2} \mathrm{O}$ \\
$\mathrm{ALH} 3$ & $\mathrm{ZrO}_{2} / \mathrm{SO}_{4}^{2-}(1 \mathrm{M})$ & $\mathrm{ZrOCl}_{2} \cdot 8 \mathrm{H}_{2} \mathrm{O}$ \\
$\mathrm{ALH} 4$ & $\mathrm{ZrO}_{2} / \mathrm{Nb}_{2} \mathrm{O}_{5}(3 \%)$ & $\mathrm{ZrOCl}_{2} \cdot 8 \mathrm{H}_{2} \mathrm{O}$ \\
$\mathrm{ALH} 5$ & $\mathrm{ZrO}_{2} / \mathrm{Nb}_{2} \mathrm{O}_{5}(5 \%)$ & $\mathrm{ZrOCl}_{2} \cdot 8 \mathrm{H}_{2} \mathrm{O}$ \\
\hline
\end{tabular}


a) Method 1: Sol-Gel in Acid Medium [8]

$20 \mathrm{~mL}$ of zirconium n-propoxide $\mathrm{Zr}(\mathrm{OPr})_{4}$ was mixed with $26.6 \mathrm{~mL}$ of n-propanol under stirring. A mixture of $0.51 \mathrm{~mL} \mathrm{H}_{2} \mathrm{SO}_{4}$ (98\% purity) and $3.2 \mathrm{~mL}$ of distilled water were added drop wise under vigorous stirring to the initial mixture which turned instantly into a white yellowish gel. After adding the acidic solution, the gel was kept for $1 \mathrm{~h}$ at room temperature, then heated at $75^{\circ} \mathrm{C}$ for $18 \mathrm{~h}$ to remove the alcohol. The temperature in the oven was raised to $120^{\circ} \mathrm{C}$ for another $12 \mathrm{~h}$. Finally the solid obtained was well ground to fine white powder and calcined at $650^{\circ} \mathrm{C}$ for $4 \mathrm{~h}$ in air to yield the in-situ sulfated zirconium oxide $\mathrm{ZrO}_{2}-\mathrm{SO}_{4}^{2-}$.

b) Method 2: Sol-Gel in Basic Medium [8]

$20 \mathrm{~mL}$ of zirconium n-propoxide $\mathrm{Zr}(\mathrm{OPr})_{4}$ was mixed with $26.6 \mathrm{~mL}$ of npropanol. An aqueous ammonia solution (33\%) was added dropwise while stirring until a $\mathrm{pH}$ range $9-10$. The gel obtained was aged for $1 \mathrm{~h}$, then it dried at room temperature for $24 \mathrm{~h}$, then at $110^{\circ} \mathrm{C}$ for another $24 \mathrm{~h}$. Finally the solid was calcined at $650^{\circ} \mathrm{C}$ for $4 \mathrm{~h}$ in air. When the sulfate ions are in-situ impregnated, it is indicated as $\mathrm{ZrO}_{2}-\mathrm{SO}_{4}^{2-}$ and when they are impregnated by post treatment (after oxide preparation), it is indicated as $\mathrm{ZrO}_{2} / \mathrm{SO}_{4}^{2-}$. A full list of zirconium oxides catalysts prepared by the sol-gel method is shown in Table 2 .

\subsubsection{Titanium Oxide Catalysts}

Titanium catalysts were prepared by three different methods. The first method was precipitation using $\mathrm{TiCl}_{4}$ as precursor, the second and third methods were the sol-gel and templated sol-gel techniques during which titanium isopropoxide $\mathrm{Ti}\left(\mathrm{O}^{\mathrm{i}} \mathrm{Pr}\right)_{4}$ was used as precursor.

\section{1) Titanium Catalysts Prepared by the Precipitation Method [9]}

$11 \mathrm{~mL}$ of titanium tetrachloride $\mathrm{TiCl}_{4}$ were added dropwise to $520 \mathrm{~mL}$ distilled water in an ice bath $\left(0.2 \mathrm{M} \mathrm{TiCl}_{4}\right)$. Ammonia solution $\left(\mathrm{NH}_{3(\mathrm{aq})} 35 \%\right)$ was added dropwise while stirring until the solution reached $\mathrm{pH} 9$. The obtained precipitate was aged for $24 \mathrm{~h}$, filtered and washed with hot distilled water until no chloride ions could be detected ( $0.5 \mathrm{M} \mathrm{AgNO}_{3(\mathrm{aq})}$ test). The obtained precipitate $\mathrm{Ti}(\mathrm{OH})_{4}$ was dried at $100^{\circ} \mathrm{C}$ for $24 \mathrm{~h}$ then calcined at $500^{\circ} \mathrm{C}$ for $5 \mathrm{~h}$. The obtained

Table 2. Zirconium catalysts prepared by sol-gel method.

\begin{tabular}{|c|c|c|c|}
\hline $\begin{array}{c}\text { Catalyst } \\
\text { code }\end{array}$ & $\begin{array}{c}\text { Catalyst } \\
\text { composition }\end{array}$ & Medium & $\begin{array}{c}\text { Batch }^{\mathrm{a}} \\
\text { Composition }\end{array}$ \\
\hline ALH 6 & $\mathrm{ZrO}_{2}$ & basic & $1 \mathrm{Zr}(\mathrm{OPr})_{4}: 10.3 \mathrm{n}$-propanol: $\left(\mathrm{NH}_{3} \mathrm{pH}=9-10\right)$ \\
\hline ALH 7 & $\mathrm{ZrO}_{2} / \mathrm{SO}_{4}^{2-} \quad(0.5 \mathrm{M})$ & basic & $1 \mathrm{Zr}(\mathrm{OPr})_{4}: 10.3 n$-propanol: $\left(\mathrm{NH}_{3} \mathrm{pH}=9-10\right)$ \\
\hline ALH 8 & $\mathrm{ZrO}_{2} / \mathrm{SO}_{4}^{2-} \quad(1 \mathrm{M})$ & basic & $1 \mathrm{Zr}(\mathrm{OPr})_{4}: 10.3 \mathrm{n}$-propanol: $\left(\mathrm{NH}_{3} \mathrm{pH}=9-10\right)$ \\
\hline ALH 9 & $\mathrm{ZrO}_{2} / \mathrm{Nb}(3 \%)$ & basic & $1 \mathrm{Zr}(\mathrm{OPr})_{4}: 10.3 \mathrm{n}$-propanol: $\left(\mathrm{NH}_{3} \mathrm{pH}=9-10\right)$ \\
\hline ALH 10 & $\mathrm{ZrO}_{2} / \mathrm{Nb}(5 \%)$ & basic & $1 \mathrm{Zr}(\mathrm{OPr})_{4}: 10.3 \mathrm{n}$-propanol:( $\left.\mathrm{NH}_{3} \mathrm{pH}=9-10\right)$ \\
\hline ALH 11 & $\mathrm{ZrO}_{2} / \mathrm{SO}_{4}^{2-}$ & acidic & $1 \mathrm{Zr}(\mathrm{OPr})_{4}: 10.3$ n-propanol:0.2 $\mathrm{H}_{2} \mathrm{SO}_{4}: 4 \mathrm{H}_{2} \mathrm{O}$ \\
\hline
\end{tabular}

a Batch composition: The batch composition refers to the product of the batch preparation stated in molar ratios of oxides, template molecules, neutralization products, reaction media, etc. 
titanium oxide support $\mathrm{TiO}_{2}$ can be further impregnated with sulfate ions or with niobium. A full list of titanium catalysts prepared by the precipitation method is show in Table 3.

\section{2) Titanium Catalysts Prepared by the Sol-Gel Method [10]}

$12.5 \mathrm{~mL}$ of Titanium isopropoxide $\mathrm{Ti}\left(\mathrm{O}^{\mathrm{i}} \mathrm{Pr}\right)_{4}$ was added to $100 \mathrm{~mL}$ of 2-propanol. $3.2 \mathrm{~mL}$ of $1 \mathrm{M} \mathrm{H}_{2} \mathrm{SO}_{4}$ solution was added drop wise under vigorous stirring. The resulting colloidal suspension was stirred for $4 \mathrm{~h}$. The gel obtained was filtered, washed with distilled water, dried at $100^{\circ} \mathrm{C}$ for $24 \mathrm{~h}$ and calcined at $400^{\circ} \mathrm{C}$ for 1 h, to finally yield $\mathrm{TiO}_{2}-\mathrm{SO}_{4}^{2-}$.

To obtain the pure $\mathrm{TiO}_{2}$, the same procedure was followed but only water was used instead of $\mathrm{H}_{2} \mathrm{SO}_{4}$. The obtained pure $\mathrm{TiO}_{2}$ will receive two separate impregnations as described before: the sulfate ions and the niobium impregnations.

3) Titanium Catalysts Prepared by the Templated Sol-Gel Method [11]

$2.36 \mathrm{~g}$ of hexadecyltrimethyl-ammonium bromide (CTAMBr) were dissolved in $24 \mathrm{~mL}$ ethanol. On another hand a mixture of $12 \mathrm{~mL} \mathrm{Ti}\left(\mathrm{O}^{\mathrm{i}} \mathrm{Pr}\right)_{4}, 22.8 \mathrm{~mL} \mathrm{EtOH}$ and $4.72 \mathrm{~mL} \mathrm{HCl}$ solutions was prepared. The first solution was added slowly to the second mixture, then $8.24 \mathrm{~mL}$ of distilled water were added drop wise to the mixture and stirred for $15 \mathrm{~min}$. The resulting mixture was transferred to a large crystallizing dish and heated at $60^{\circ} \mathrm{C}$ for 7 days. A yellowish solid was obtained and further received a stabilization step with $\mathrm{NaOH}$, where $50 \mathrm{~mL}$ of $0.112 \mathrm{M}$ $\mathrm{NaOH}$ solution were added, and the suspension was refluxed for $48 \mathrm{~h}$. After filtration the solid obtained was washed with distilled water, dried at room temperature and calcined at $300^{\circ} \mathrm{C}$ for $1 \mathrm{~h}$ to yield $\mathrm{TiO}_{2}$.

The obtained pure $\mathrm{TiO}_{2}$ was subjected to two separate impregnations as described before: the sulfate ions impregnation and the niobium impregnation. A full list of titanium catalysts prepared by the sol-gel and templated sol-gel method is shown in Table 4.

\subsubsection{Hafnium Oxide Catalysts [12]}

$10 \mathrm{~g}$ of hafnium tetrachloride $\mathrm{HfCl}_{4}$ were dissolved in $200 \mathrm{~mL}$ distilled water. To this solution a $0.4 \mathrm{M}$ aqueous solution of $\mathrm{KOH}$ were slowly added dropwise while stirring. The suspension was stirred for $3 \mathrm{~h}$. In this particular case the precipitate was difficult to filtrate, therefore it was centrifuged at $4000 \mathrm{rpm}$ for 10 min and washed with distilled water, The process was repeated several times until the precipitate was free of chloride ions $\left(0.5 \mathrm{M} \mathrm{AgNO}_{3(\mathrm{aq})}\right.$ test). The obtained

Table 3. Titanium catalysts prepared by precipitation method.

\begin{tabular}{ccc}
\hline $\begin{array}{c}\text { Catalyst } \\
\text { code }\end{array}$ & $\begin{array}{c}\text { Catalyst } \\
\text { composition }\end{array}$ & Precursor \\
\hline $\mathrm{ALH} 12$ & $\mathrm{TiO}_{2}$ & $\mathrm{TiCl}_{4}$ \\
$\mathrm{ALH} \mathrm{13}$ & $\mathrm{TiO}_{2} / \mathrm{SO}_{4}^{2-} \quad(0.5 \mathrm{M})$ & $\mathrm{TiCl}_{4}$ \\
$\mathrm{ALH} 14$ & $\mathrm{TiO}_{2} / \mathrm{SO}_{4}^{2-} \quad(1 \mathrm{M})$ & $\mathrm{TiCl}_{4}$ \\
$\mathrm{ALH} 15$ & $\mathrm{TiO}_{2} / \mathrm{Nb}(3 \%)$ & $\mathrm{TiCl}_{4}$ \\
$\mathrm{ALH} \mathrm{16}$ & $\mathrm{TiO}_{2} / \mathrm{Nb}(5 \%)$ & $\mathrm{TiCl}_{4}$ \\
\hline
\end{tabular}


Table 4. Titanium catalysts prepared by both sol-gel methods.

\begin{tabular}{|c|c|c|}
\hline $\begin{array}{l}\text { Catalyst } \\
\text { code }\end{array}$ & $\begin{array}{c}\text { Catalyst } \\
\text { composition }\end{array}$ & $\begin{array}{c}\text { Batch } \\
\text { composition }\end{array}$ \\
\hline ALH 17 & $\mathrm{TiO}_{2}$ & $1 \mathrm{Ti}\left(\mathrm{O}^{\mathrm{i}} \mathrm{Pr}\right)_{4}: 32.68 \mathrm{n}$-propanol: $4.34 \mathrm{H}_{2} \mathrm{O}$ \\
\hline ALH 18 & $\mathrm{TiO}_{2}-\mathrm{SO}_{4}^{2-} \quad(1 \mathrm{M})$ & $1 \mathrm{Ti}\left(\mathrm{O}^{\mathrm{i}} \mathrm{Pr}\right)_{4}: 32.68 \mathrm{n}$-propanol:0.078 $\mathrm{H}_{2} \mathrm{SO}_{4}: 3.91 \mathrm{H}_{2} \mathrm{O}$ \\
\hline ALH 19 & $\mathrm{TiO}_{2} / \mathrm{SO}_{4}^{2-} \quad(0.5 \mathrm{M})$ & $1 \mathrm{Ti}\left(\mathrm{O}^{\mathrm{i}} \mathrm{Pr}\right)_{4}: 32.68 \mathrm{n}$-propanol: $4.34 \mathrm{H}_{2} \mathrm{O}$ \\
\hline ALH 20 & $\mathrm{TiO}_{2} / \mathrm{SO}_{4}^{2-} \quad(1 \mathrm{M})$ & $1 \mathrm{Ti}\left(\mathrm{O}^{\mathrm{i}} \mathrm{Pr}\right)_{4}: 32.68 \mathrm{n}$-propanol:4.34 $\mathrm{H}_{2} \mathrm{O}$ \\
\hline ALH 21 & $\mathrm{TiO}_{2} / \mathrm{Nb}(3 \%)$ & $1 \mathrm{Ti}\left(\mathrm{O}^{\mathrm{i}} \mathrm{Pr}\right)_{4}: 32.68$ n-propanol: $4.34 \mathrm{H}_{2} \mathrm{O}$ \\
\hline ALH 22 & $\mathrm{TiO}_{2} / \mathrm{Nb}(5 \%)$ & $1 \mathrm{Ti}\left(\mathrm{O}^{\mathrm{i}} \mathrm{Pr}\right)_{4}: 32.68 \mathrm{n}$-propanol: $4.34 \mathrm{H}_{2} \mathrm{O}$ \\
\hline ALH 23 & $\mathrm{TiO}_{2}$ & $1 \mathrm{Ti}\left(\mathrm{O}^{\mathrm{i} P r}\right)_{4}: 0.16 \mathrm{CTAB}: 1.4 \mathrm{HCl}: 17 \mathrm{H}_{2} \mathrm{O}: 20 \mathrm{EtOH}$ \\
\hline ALH 24 & $\mathrm{TiO}_{2} / \mathrm{SO}_{4}^{2-} \quad(0.5 \mathrm{M})$ & $1 \mathrm{Ti}\left(\mathrm{O}^{\mathrm{i} P r}\right)_{4}: 0.16 \mathrm{CTAB}: 1.4 \mathrm{HCl}: 17 \mathrm{H}_{2} \mathrm{O}: 20 \mathrm{EtOH}$ \\
\hline ALH 25 & $\mathrm{TiO}_{2} / \mathrm{SO}_{4}^{2-} \quad(1 \mathrm{M})$ & $1 \mathrm{Ti}\left(\mathrm{O}^{\mathrm{i} P r}\right)_{4}: 0.16 \mathrm{CTAB}: 1.4 \mathrm{HCl}: 17 \mathrm{H}_{2} \mathrm{O}: 20 \mathrm{EtOH}$ \\
\hline ALH 26 & $\mathrm{TiO}_{2} / \mathrm{Nb}(3 \%)$ & $1 \mathrm{Ti}\left(\mathrm{O}^{\mathrm{i}} \mathrm{Pr}\right)_{4}: 0.16 \mathrm{CTAB}: 1.4 \mathrm{HCl}: 17 \mathrm{H}_{2} \mathrm{O}: 20 \mathrm{EtOH}$ \\
\hline ALH 27 & $\mathrm{TiO}_{2} / \mathrm{Nb}(5 \%)$ & $1 \mathrm{Ti}\left(\mathrm{O}^{\mathrm{i} P r}\right)_{4}: 0.16 \mathrm{CTAB}: 1.4 \mathrm{HCl}: 17 \mathrm{H}_{2} \mathrm{O}: 20 \mathrm{EtOH}$ \\
\hline
\end{tabular}

$\mathrm{Hf}(\mathrm{OH})_{4}$ precipitate was dried in an oven at $100^{\circ} \mathrm{C}$ for $1 \mathrm{~h}$. Further calcination at $500^{\circ} \mathrm{C}$ for $2 \mathrm{~h}$ formed $\mathrm{HfO}_{2}$. The obtained hafnium oxide was impregnated with sulfate ions and niobium as described before.

A full list of hafnium catalysts prepared by precipitation is shown in Table 5 .

\subsubsection{MCM-41 Prepared Materials [13]}

Two well-known families of highly ordered mesoporous silica materials (MCM-41 and SBA-15) were prepared by the templated sol-gel method, using two types of surfactants; the cationic surfactant hexadecyltrimethyl-ammonium bromide CTAMBr and the non-ionic block copolymer pluronic P123, respectively and using tetraethyl orthosilicate (TEOS) as silica precursor.

These materials were subjected to three separate treatments; in the first, niobium was incorporated into the framework of the material during preparation to get Nb-MCM-41 and Nb-SBA-15. In the second, niobium was loaded on the surface of the materials by post impregnation using an aqueous solution of niobium oxalate and oxalic acid. In the third, impregnation with sulfate ion was realized using aqueous solution of known concentration of sulfuric acid.

1) Nb-MCM-41 Catalyst

$9.6 \mathrm{~g}$ of hexadecyltrimethyl-ammonium bromide (CTAMBr) were dissolved in $200 \mathrm{~mL}$ of distilled water and $200 \mathrm{~mL}$ ethanol. $61.2 \mathrm{~mL}$ of aqueous ammonia solution ( $32 \mathrm{wt} . \%$ ) were added to the surfactant solution. The mixture was stirred for $10 \mathrm{~min}$ and $14.46 \mathrm{~mL}$ of TEOS and $1.07 \mathrm{~g}$ of niobium oxalate were added (the niobium oxalate mass was calculated to get a $\mathrm{Si} / \mathrm{Nb}$ ratio of 32 ). After stirring for $2 \mathrm{~h}$ the resulting solid was recovered by filtration, washed with distilled water and dried in air. The template was removed by calcination at $550^{\circ} \mathrm{C}$ for $8 \mathrm{~h}$.

\section{2) MCM-41 Catalyst}

To obtain the bare MCM-41, the same procedure is followed as previously, but without adding niobium precursor. A full list of meso-structured silica 
Table 5. List of hafnium catalysts prepared by precipitation method.

\begin{tabular}{ccc}
\hline $\begin{array}{c}\text { Catalyst } \\
\text { code }\end{array}$ & $\begin{array}{c}\text { Catalyst } \\
\text { composition }\end{array}$ & Precursor \\
\hline $\mathrm{ALH} 28$ & $\mathrm{HfO}_{2}$ & $\mathrm{HfCl}_{4}$ \\
$\mathrm{ALH} 29$ & $\mathrm{HfO}_{2} / \mathrm{SO}_{4}^{2-}(0.5 \mathrm{M})$ & $\mathrm{HfCl}_{4}$ \\
$\mathrm{ALH} \mathrm{30}$ & $\mathrm{HfO}_{2} / \mathrm{SO}_{4}^{2-}(1 \mathrm{M})$ & $\mathrm{HfCl}_{4}$ \\
$\mathrm{ALH} \mathrm{31}$ & $\mathrm{HfO}_{2} / \mathrm{Nb}(3 \%)$ & $\mathrm{HfCl}_{4}$ \\
$\mathrm{ALH} 32$ & $\mathrm{HfO}_{2} / \mathrm{Nb}(5 \%)$ & $\mathrm{HfCl}_{4}$ \\
\hline
\end{tabular}

MCM-41 catalysts prepared by templated sol-gel method is shown in Table 6 .

\subsubsection{SBA-15 Prepared Materials [13]}

\section{1) Nb-SBA-15 Catalysts}

$6 \mathrm{~g}$ of (PEG-PPG-PEG) Pluronic P-123 were dissolved in $132 \mathrm{~mL}$ of $0.63 \mathrm{M}$ $\mathrm{HCl}$ solution (the complete dissolution of the surfactant took about $3 \mathrm{~h}$ ). Afterwards, $12.76 \mathrm{~mL}$ of tetraethyl orthosilicate TEOS and $0.94 \mathrm{~g}$ of niobium oxalate were added in order to get a $\mathrm{Si} / \mathrm{Nb}$ atomic ratio of 32 . The mixture was stirred at $60^{\circ} \mathrm{C}$ for $8 \mathrm{~h}$. Then left at $80^{\circ} \mathrm{C}$ for $16 \mathrm{~h}$. The precipitate was filtered, washed with distilled water and dried at $60^{\circ} \mathrm{C}$ for $24 \mathrm{~h}$. After calcination at $550^{\circ} \mathrm{C}$ for $8 \mathrm{~h}$ in air, the mesoporous Nb-SBA-15 was obtained.

\section{2) SBA-15 Catalysts}

To prepare the pure SBA-15, the previous procedure is followed but without adding the niobium oxalate. A full list of SBA-15 catalysts prepared by templated sol-gel method is shown in Table 7.

\subsection{Catalysts Characterizations}

All catalysts used in this work were prepared by known published methods in the literature, therefore both morphological properties of these solids (surface area and crystalline phase) were taken from these references, which will be detailed in the results and discussions part. As mentioned earlier The acidity of all the prepared solid acid catalysts were measured by previously reported titrimetric method [6], the results of acidity measurements are listed in tables for each set of catalysts.

\subsection{Catalytic Test}

General procedure for 2-naphtol etherification: In a typical run, $1.4417 \mathrm{~g}$ (10 $\mathrm{mmol}$ ) of 2-naptol and $9.1 \mathrm{ml}$ of butanol (10 eq) were added to $0.28 \mathrm{~g}$ of catalyst (20 wt.\%), the reaction mixture was stirred and the temperature was maintained at $115^{\circ} \mathrm{C}$ (reflux). After $24 \mathrm{~h}$, the reaction mixture was cooled down to room temperature and filtered. The catalyst was thoroughly washed with ethyl acetate. The filtrate was concentrated under vacuum to give the crude product and to eliminate butanol.

The main products for the solid acid-catalyzed etherification of 2-naphtol and the reaction are as follows in Scheme 1. 
Table 6. MCM-41 catalysts prepared.

\begin{tabular}{|c|c|c|}
\hline $\begin{array}{l}\text { Catalyst } \\
\text { code }\end{array}$ & $\begin{array}{c}\text { Catalyst } \\
\text { composition }\end{array}$ & $\begin{array}{c}\text { Batch } \\
\text { composition }\end{array}$ \\
\hline ALH 33 & MCM-41 & 1 TEOS:0.4CATB:52.5EtOH:16.01 $\mathrm{NH}_{3}: 170.5 \mathrm{H}_{2} \mathrm{O}$ \\
\hline ALH 34 & Nb-MCM-41 & 1 TEOS:0.4CATB:0.031NbOx:52.5EtOH: $16.01 \mathrm{NH}_{3}: 170.5 \mathrm{H}_{2} \mathrm{O}$ \\
\hline ALH 35 & $\begin{array}{c}\mathrm{MCM}-41 / \mathrm{SO}_{4}^{2-} \\
(0.5 \mathrm{M})\end{array}$ & 1 TEOS:0.4CATB:52.5EtOH:16.01 $\mathrm{NH}_{3}: 170.5 \mathrm{H}_{2} \mathrm{O}$ \\
\hline ALH 36 & $\mathrm{MCM}-41 / \mathrm{SO}_{4}^{2-} \quad(1 \mathrm{M})$ & 1 TEOS:0.4CATB:52.5EtOH:16.01 $\mathrm{NH}_{3}: 170.5 \mathrm{H}_{2} \mathrm{O}$ \\
\hline ALH 37 & $\mathrm{MCM}-41 / \mathrm{Nb}(3 \%)$ & 1 TEOS:0.4CATB:52.5 EtOH:16.01 NH $\mathrm{NH}_{3}: 170.5 \mathrm{H}_{2} \mathrm{O}$ \\
\hline ALH 38 & $\mathrm{MCM}-41 / \mathrm{Nb}(5 \%)$ & 1 TEOS:0.4 CATB:52.5 EtOH:16.01 NH $3: 170.5 \mathrm{H}_{2} \mathrm{O}$ \\
\hline
\end{tabular}

Table 7. SBA-15 catalysts prepared.

\begin{tabular}{|c|c|c|}
\hline $\begin{array}{c}\text { Catalyst } \\
\text { code }\end{array}$ & $\begin{array}{c}\text { Catalyst } \\
\text { composition }\end{array}$ & $\begin{array}{c}\text { Batch } \\
\text { composition }\end{array}$ \\
\hline ALH 39 & SBA-15 & 1 TEOS:0.017P123:1.44HCl:120.67 $\mathrm{H}_{2} \mathrm{O}$ \\
\hline ALH 40 & $\mathrm{Nb}-\mathrm{SBA}-15$ & 1 TEOS:0.017P123:1.44HCl:0.031NbOx:120.67H $\mathrm{H}_{2} \mathrm{O}$ \\
\hline ALH 41 & $\mathrm{SBA}-15 / \mathrm{SO}_{4}^{2-} \quad(0.5 \mathrm{M})$ & 1 TEOS:0.017P123:1.44HCl:120.67 $\mathrm{H}_{2} \mathrm{O}$ \\
\hline ALH 42 & SBA-15/ $\mathrm{SO}_{4}^{2-} \quad(1 \mathrm{M})$ & 1 TEOS:0.017P123:1.44HCl:120.67 $\mathrm{H}_{2} \mathrm{O}$ \\
\hline ALH 43 & SBA-15/Nb (3\%) & 1 TEOS:0.017P123:1.44HCl:120.67 $\mathrm{H}_{2} \mathrm{O}$ \\
\hline ALH 44 & SBA-15/Nb (5\%) & 1 TEOS:0.017P123:1.44HCl:120.67- $\mathrm{H}_{2} \mathrm{O}$ \\
\hline
\end{tabular}<smiles></smiles>

Scheme 1. Etherification reaction of 2-naphtol with 1-butanol.

The crude was purified by silica column chromatography (hexane/ethyl acetate: 9/1). The conversions were calculated based on the limiting reactant (2-naphtol), also the yields of the other products were determined from the mass of the obtained fractions from the silica column separation.

In all cases, butanol was taken in excess (10 eq) with respect to 2-naphthol to drive the equilibrium toward ether formation. It was interesting to note that the reaction mixture released a remarkable odor, a fruity raspberry/strawberry taste, of 2-butoxy-naphthyl ether as the reaction proceeded.

Characterization of the products:

2-butoxynaphthalene (2) 
${ }^{1} \mathrm{H}$ NMR (300 MHz, $\left.\mathrm{CDCl}_{3}, \delta \mathrm{ppm}\right): 7.75(\mathrm{~d}, 1 \mathrm{~h}), 7.72(\mathrm{~d}, 2 \mathrm{H}), 7.43(\mathrm{t}, 1 \mathrm{~h})$, 7.33 (t, 1 h), $7.16(\mathrm{~d}, 1 \mathrm{~h}), 7.14(\mathrm{~s}, 1 \mathrm{~h}), 4.09(\mathrm{t}, 2 \mathrm{H}), 1.85(\mathrm{~m}, 2 \mathrm{H}), 1.54(\mathrm{~m}, 2 \mathrm{H})$, 1.01 (t, 3 h). ${ }^{13} \mathrm{C}$ NMR (75 MHz, $\left.\mathrm{CDCl}_{3}\right): 157.3(\mathrm{Cq}), 134.8(\mathrm{Cq}), 129.4(\mathrm{CH})$, $129.0(\mathrm{Cq}), 127.8(\mathrm{CH}), 126.8(\mathrm{CH}), 126.4(\mathrm{CH}), 123.6(\mathrm{CH}), 119.2(\mathrm{CH}), 106.7$ (CH), $67.8\left(\mathrm{CH}_{2}\right), 31.4\left(\mathrm{CH}_{2}\right), 19.5\left(\mathrm{CH}_{2}\right), 14.0\left(\mathrm{CH}_{3}\right) . \mathrm{mp}<50^{\circ} \mathrm{C}$ (yellow solid), $\mathrm{R}_{\mathrm{f}}: 0.55$ (aluminum sheets coated with silica gel Merck $60 \mathrm{~F} 2540.25 \mathrm{~mm}$, hexane/ethyl acetate: 9/1).

4-propyldinaphtho[2,1-d:1',2'-f] [1,3]dioxepine (3)

${ }^{1} \mathrm{H}$ NMR (300 MHz, $\left.\mathrm{CDCl}_{3}, \delta \mathrm{ppm}\right): 8.28(\mathrm{~d}, 2 \mathrm{H}), 7.90(\mathrm{~d}, 2 \mathrm{H}), 7.80(\mathrm{~d}, 2 \mathrm{H})$, $7.64(\mathrm{t}, 2 \mathrm{H}), 7.48(\mathrm{t}, 2 \mathrm{H}), 7.41(\mathrm{~d}, 2 \mathrm{H}), 5.58(\mathrm{t}, 1 \mathrm{~h}), 2.03(\mathrm{~m}, 2 \mathrm{H}), 1.03(\mathrm{~m}, 2 \mathrm{H})$, 0.63 (t, $3 \mathrm{~h}) .{ }^{13} \mathrm{C}$ NMR $\left(75 \mathrm{MHz}, \mathrm{CDCl}_{3}\right): 14.21\left(\mathrm{CH}_{3}\right), 18.25\left(\mathrm{CH}_{2}\right), 31.17\left(\mathrm{CH}_{2}\right)$, $38.31\left(\mathrm{CH}_{3}\right), 116.82(2 \mathrm{CH}), 117.68(2 \mathrm{CH}), 122.58(2 \mathrm{CH}), 124.19(2 \mathrm{CH}), 126.69$ (2 CH), 128.27 (2 CH), $128.96(2 \mathrm{CH}), 131.14$ (2 Cq), 131.57 (2 Cq), 150.08 (2 Cq). $\mathrm{mp} 220^{\circ} \mathrm{C}-222^{\circ} \mathrm{C}$ (light brown solid). $\mathrm{R}_{\mathrm{f}}: 0.45$ (aluminum sheets coated with silica gel Merck 60 F254 $0.25 \mathrm{~mm}$, hexane/ethyl acetate: 9/1).

2-ethylnaphtho[2,1-b]furan (4)

${ }^{1} \mathrm{H}$ NMR (300 MHz, $\left.\mathrm{CDCl}_{3}, \delta \mathrm{ppm}\right): 8.13$ (d, 1 h), 7.97 (d, 1 h), 7.67 (d, 1 h), 7.65 (d, 1 h), 7.59 (t, 1 h), 7.49 (t, 1 h), 6.9 (s, 1 h), 2.92 (q, 2H), $1.44\left(\mathrm{t}, 3\right.$ h). ${ }^{13} \mathrm{C}$ $\operatorname{NMR}\left(75 \mathrm{MHz}, \mathrm{CDCl}_{3}\right): 160.44(\mathrm{Cq}), 151.95(\mathrm{Cq}), 130.35(\mathrm{Cq}), 128.79(\mathrm{CH})$, $127.61(\mathrm{Cq}), 126.01(\mathrm{CH}), 124.25(\mathrm{CH}), 123.93(\mathrm{CH}), 123.53(\mathrm{CH}), 112.24(\mathrm{CH})$, $100.26(\mathrm{CH}), 22.1\left(\mathrm{CH}_{2}\right), 12.26\left(\mathrm{CH}_{3}\right) . \mathrm{mp}<50^{\circ} \mathrm{C}$ (grey solid), $\mathrm{R}_{\mathrm{f}}: 0.5$ (aluminum sheets coated with silica gel Merck 60 F254 $0.25 \mathrm{~mm}$, hexane/ethyl acetate: 9/1).

[1,1'-binaphthalene]-2,2'-diol (BINAP) (5)

${ }^{1} \mathrm{H}$ NMR $\left(300 \mathrm{MHz}, \mathrm{CDCl}_{3}, \delta \mathrm{ppm}\right): 8(\mathrm{~d}, 2 \mathrm{H}), 7.91(\mathrm{~d}, 2 \mathrm{H}), 7.41(\mathrm{~d}, 2 \mathrm{H}), 7.36$ (t, 2H), $7.31(\mathrm{t}, 2 \mathrm{H}), 7.17(\mathrm{~d}, 2 \mathrm{H}) .{ }^{13} \mathrm{C}$ NMR $\left(75 \mathrm{MHz}, \mathrm{CDCl}_{3}\right): 150.8(2 \mathrm{Cq})$, $132.06(2 \mathrm{Cq}), 129.54(2 \mathrm{CH}), 127.08(2 \mathrm{Cq}), 126.85(2 \mathrm{CH}), 124.76(2 \mathrm{CH})$, $123.28(2 \mathrm{CH}), 121.22(2 \mathrm{CH}), 117.46(2 \mathrm{CH}), 113.28(2 \mathrm{Cq}) . \mathrm{mp} 210^{\circ} \mathrm{C}-213^{\circ} \mathrm{C}$ (light brown solid), $\mathrm{R}_{\mathrm{f}}: 0.1$ (aluminum sheets coated with silica gel Merck 60 F254 $0.25 \mathrm{~mm}$, hexane/ethyl acetate: 9/1).

\section{Results and Discussions}

\subsection{Optimization of Catalyst Loading}

Since this reaction had been done with known solid acid catalysts like amberlyst-15 and Nafion [14], and its conditions (reaction time and temperature) were already optimized, it was only necessary for us to find the optimal catalyst loading that will yield the most of the aromatic ether 2-butoxynaphtalene (2). For this purpose, one specific catalyst was chosen, the $\mathrm{ZrO}_{2} / \mathrm{SO}_{4}^{2-}(1 \mathrm{M}) \mathrm{ALH} 8$. These optimal conditions were applied for all the following catalytic tests done with the remaining catalysts.

Optimal catalyst loading was determined for higher 2-butoxynaphtalene (2) yields. Etherification of 2-naphtol was done following the general procedure detailed previously (Section 2.5), but in this case several catalyst loadings were tested using as mentioned before $\mathrm{ZrO}_{2} / \mathrm{SO}_{4}^{2-}(1 \mathrm{M}) \mathrm{ALH} 8$ to determine which 
gave the best yields $(0.07 \mathrm{~g}, 0.14 \mathrm{~g}, 0.28 \mathrm{~g}, 0.43 \mathrm{~g}$ and $0.57 \mathrm{~g})$. The obtained results are shown in Figure 1.

As shown in Figure 1, when the catalyst amount is increased from $0.07 \mathrm{~g}$ (5 wt.\%) to $0.28 \mathrm{~g}$ ( $20 \mathrm{wt} . \%$ ), the yield of 2-butoxynaphtalene (2) increases from 5 to $31 \%$. Above $0.28 \mathrm{~g}$ ( $20 \mathrm{wt} . \%$ ) of the catalyst, no significant change in the obtained yield. The optimum catalyst loading is found to be $0.28 \mathrm{~g}$ (20 wt.\%) for the optimal formation of 2-butoxynaphtalene (2).

\subsection{Catalysts Characterizations}

In this part, we present in details both properties (surface area and crystalline phase) for some of the prepared catalysts taken from the references that were used to prepare them as mentioned before. We present also the surface acidity titrations for all prepared catalysts will be given.

\subsubsection{Zirconium Oxide Catalysts Characterization}

The sulfated zirconia $\mathrm{ZrO}_{2} / \mathrm{SO}_{4}^{2-}(1 \mathrm{M}) \mathrm{ALH} 3$, prepared by the precipitation method has a surface area of $65.3 \mathrm{~m}^{2} / \mathrm{g}$. On the other hand the in-situ sulfated zirconia ALH 11 prepared by the sol-gel method in acid medium has a higher surface area of $88 \mathrm{~m}^{2} / \mathrm{g}$, but the sulfated zirconia ALH 7 prepared by the sol-gel method in basic medium showed the highest surface area of $101 \mathrm{~m}^{2} / \mathrm{g}$. all three catalysts showed tetragonal phases. The surface acidity measurements for both series of zirconium catalysts prepared by the precipitation and the sol-gel method (acid and basic medium) are listed in Table 8 and Table 9.

Comparing the acidity measurement results in Table 8 and Table 9, we can see a general trend, where the none impregnated oxide has the lowest acidity. This was expected since metal oxides are known to have very weak to non-surface acidity. Impregnation with niobium showed very weak acidity with no significant difference between both niobium loadings chosen (3\% and 5\%). These obtained acidity measurements were expected since in literature only sulfated metal oxides are the most acidic (super acidic).

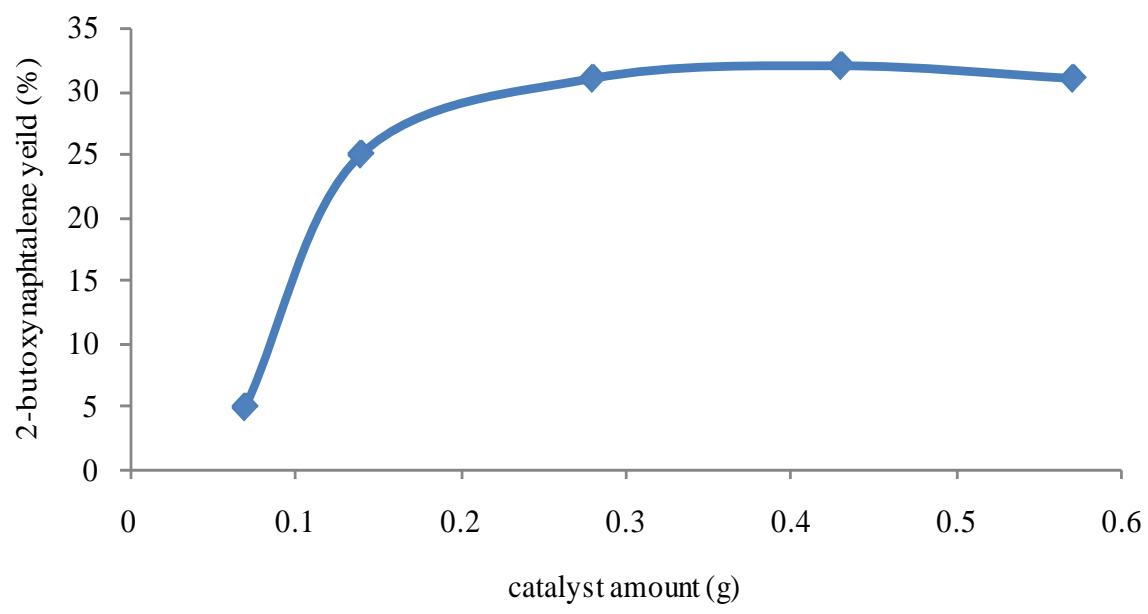

Figure 1. Effect of catalyst amount on butoxynaphtalene yield. 
Table 8. Acidity measurements of zirconium catalysts prepared by precipitation method.

\begin{tabular}{ccc}
\hline $\begin{array}{c}\text { Catalyst } \\
\text { code }\end{array}$ & $\begin{array}{c}\text { Catalyst } \\
\text { composition }\end{array}$ & $\begin{array}{c}\text { Acidity } \\
\mathbf{n}^{\mathrm{H+}}(\mathbf{m m o l} / \mathbf{g})\end{array}$ \\
\hline $\mathrm{ALH} 1$ & $\mathrm{ZrO}_{2}$ & 1.5 \\
$\mathrm{ALH} 2$ & $\mathrm{ZrO}_{2} / \mathrm{SO}_{4}^{2-}(0.5 \mathrm{M})$ & 8 \\
$\mathrm{ALH} \mathrm{3}$ & $\mathrm{ZrO}_{2} / \mathrm{SO}_{4}^{2-} \quad(1 \mathrm{M})$ & 9.2 \\
$\mathrm{ALH} 4$ & $\mathrm{ZrO}_{2} / \mathrm{Nb}(3 \%)$ & 3.1 \\
$\mathrm{ALH} 5$ & $\mathrm{ZrO}_{2} / \mathrm{Nb}(5 \%)$ & 3 \\
\hline
\end{tabular}

Table 9. Acidity measurements of zirconium catalysts prepared by sol-gel method.

\begin{tabular}{ccc}
\hline $\begin{array}{c}\text { Catalyst } \\
\text { code }\end{array}$ & $\begin{array}{c}\text { Catalyst } \\
\text { composition }\end{array}$ & $\begin{array}{c}\text { Acidity } \\
\mathbf{n}^{\mathrm{H+}}(\mathbf{m m o l} / \mathbf{g})\end{array}$ \\
\hline $\mathrm{ALH} 6$ & $\mathrm{ZrO}_{2}$ & 1.6 \\
$\mathrm{ALH} 7$ & $\mathrm{ZrO}_{2} / \mathrm{SO}_{4}^{2-}(0.5 \mathrm{M})$ & 8.5 \\
$\mathrm{ALH} 8$ & $\mathrm{ZrO}_{2} / \mathrm{SO}_{4}^{2-} \quad(1 \mathrm{M})$ & 9.8 \\
$\mathrm{ALH} 9$ & $\mathrm{ZrO}_{2} / \mathrm{Nb}(3 \%)$ & 3.2 \\
$\mathrm{ALH} \mathrm{10}$ & $\mathrm{ZrO}_{2} / \mathrm{Nb}(5 \%)$ & 3.3 \\
$\mathrm{ALH} \mathrm{11}$ & $\mathrm{ZrO}_{2}-\mathrm{SO}_{4}^{2-}$ & 10.5 \\
\hline
\end{tabular}

\subsubsection{Titanium Oxide Catalysts Characterization}

The sulfated titanium $\mathrm{TiO}_{2} / \mathrm{SO}_{4}^{2-}(0.5 \mathrm{M})$ ALH 13 prepared by precipitation method has a surface area of $104 \mathrm{~m}^{2} / \mathrm{g}$. The in-situ sulfated titanium catalyst $\mathrm{TiO}_{2}-\mathrm{SO}_{4}^{2-}$ (1M) ALH 18 prepared by the sol-gel method has a surface area of $142.8 \mathrm{~m}^{2} / \mathrm{g}$ and the titanium catalyst $\mathrm{TiO}_{2} \mathrm{ALH} 23$ prepared by the templated sol-gel method has the largest surface area of $250 \mathrm{~m}^{2} / \mathrm{g}$. All three titanium catalysts showed Anatase phases. All surface acidity measurements are listed in Tables 10-12.

From the acidity measurements of all titanium catalysts prepared in Tables $10-12$, it was clear that the surface acidity variations of these oxides followed the same direction seen with the acidity variations of zirconium oxides, and this observation will also be seen with the rest of catalysts prepared $\left(\mathrm{HfO}_{2}, \mathrm{MCM}-41\right.$ and SBA-15).

\subsubsection{Hafnium Oxide Catalysts Characterization}

The hafnium catalysts prepared by the precipitation method showed pure monoclinic phase. No data was present regarding the surface area of hafnium oxide $\mathrm{HfO}_{2}$ ALH 28. The surface acidity measurements for all hafnium catalysts are listed in Table 13.

Again as mentioned previously the surface acidity variations of hafnium catalysts followed the same trend observed with zirconium and titanium catalysts.

\subsubsection{Meso-Structured Silicon Oxide Based Catalysts}

1) MCM-41 Catalysts 
Table 10. Acidity measurements of titanium oxide prepared by the precipitation method.

\begin{tabular}{ccc}
\hline $\begin{array}{c}\text { Catalyst } \\
\text { code }\end{array}$ & $\begin{array}{c}\text { Catalyst } \\
\text { composition }\end{array}$ & $\begin{array}{c}\text { Acidity } \\
\mathbf{n}^{\mathrm{H+}}(\mathbf{m m o l} / \mathbf{g})\end{array}$ \\
\hline $\mathrm{ALH} \mathrm{12}$ & $\mathrm{TiO}_{2}$ & 1.1 \\
$\mathrm{ALH} \mathrm{13}$ & $\mathrm{TiO}_{2} / \mathrm{SO}_{4}^{2-} \quad(0.5 \mathrm{M})$ & 6.2 \\
$\mathrm{ALH} \mathrm{14}$ & $\mathrm{TiO}_{2} / \mathrm{SO}_{4}^{2-} \quad(1 \mathrm{M})$ & 6.8 \\
$\mathrm{ALH} 15$ & $\mathrm{TiO}_{2} / \mathrm{Nb}(3 \%)$ & 2.1 \\
$\mathrm{ALH} 16$ & $\mathrm{TiO}_{2} / \mathrm{Nb}(5 \%)$ & 2 \\
\hline
\end{tabular}

Table 11. Acidity measurements of titanium catalysts prepared by sol-gel method.

\begin{tabular}{ccc}
\hline $\begin{array}{c}\text { Catalyst } \\
\text { code }\end{array}$ & $\begin{array}{c}\text { Catalyst } \\
\text { composition }\end{array}$ & $\begin{array}{c}\text { Acidity } \\
\mathbf{n}^{\mathrm{H+}}(\mathbf{m m o l} / \mathbf{g})\end{array}$ \\
\hline $\mathrm{ALH} 17$ & $\mathrm{TiO}_{2}$ & 0.9 \\
$\mathrm{ALH} 18$ & $\mathrm{TiO}_{2}-\mathrm{SO}_{4}^{2-}(1 \mathrm{M})$ & 7.9 \\
$\mathrm{ALH} 19$ & $\mathrm{TiO}_{2} / \mathrm{SO}_{4}^{2-}(0.5 \mathrm{M})$ & 6 \\
$\mathrm{ALH} 20$ & $\mathrm{TiO}_{2} / \mathrm{SO}_{4}^{2-}(1 \mathrm{M})$ & 6.1 \\
$\mathrm{ALH} 21$ & $\mathrm{TiO}_{2} / \mathrm{Nb}(3 \%)$ & 1.8 \\
$\mathrm{ALH} 22$ & $\mathrm{TiO}_{2} / \mathrm{Nb}(5 \%)$ & 2 \\
\hline
\end{tabular}

Table 12. Acidity measurements of titanium catalysts prepared by template sol-gel method.

\begin{tabular}{ccc}
\hline $\begin{array}{c}\text { Catalyst } \\
\text { Code }\end{array}$ & $\begin{array}{c}\text { Catalyst } \\
\text { composition }\end{array}$ & $\begin{array}{c}\text { Acidity } \\
\mathbf{n}^{\mathrm{H+}}(\mathbf{m m o l} / \mathbf{g})\end{array}$ \\
\hline $\mathrm{ALH} 23$ & $\mathrm{TiO}_{2}$ & 0.9 \\
$\mathrm{ALH} 24$ & $\mathrm{TiO}_{2} / \mathrm{SO}_{4}^{2-}(0.5 \mathrm{M})$ & 6.5 \\
$\mathrm{ALH} 25$ & $\mathrm{TiO}_{2} / \mathrm{SO}_{4}^{2-}(1 \mathrm{M})$ & 6.7 \\
$\mathrm{ALH} 26$ & $\mathrm{TiO}_{2} / \mathrm{Nb}(3 \%)$ & 1.9 \\
$\mathrm{ALH} 27$ & $\mathrm{TiO}_{2} / \mathrm{Nb}(5 \%)$ & 2 \\
\hline
\end{tabular}

Table 13. Acidity measurements of hafnium catalysts prepared by the precipitation method.

\begin{tabular}{ccc}
\hline $\begin{array}{c}\text { Catalyst } \\
\text { code }\end{array}$ & $\begin{array}{c}\text { Catalyst } \\
\text { composition }\end{array}$ & $\begin{array}{c}\text { Acidity } \\
\mathbf{n}^{\mathrm{H+}}(\mathbf{m m o l} / \mathbf{g})\end{array}$ \\
\hline $\mathrm{ALH} 28$ & $\mathrm{HfO}_{2}$ & 2.6 \\
$\mathrm{ALH} 29$ & $\mathrm{HfO}_{2} / \mathrm{SO}_{4}^{2-} \quad(0.5 \mathrm{M})$ & 12 \\
$\mathrm{ALH} 30$ & $\mathrm{HfO}_{2} / \mathrm{SO}_{4}^{2-}(1 \mathrm{M})$ & 14 \\
$\mathrm{ALH} 31$ & $\mathrm{HfO}_{2} / \mathrm{Nb}(3 \%)$ & 3.5 \\
$\mathrm{ALH} \mathrm{32}$ & $\mathrm{HfO}_{2} / \mathrm{Nb}(5 \%)$ & 4 \\
\hline
\end{tabular}

Both prepared samples MCM-41 and Nb-MCM-41 corresponding to ALH 33 and ALH 34 respectively, showed typical hexagonal arrangement of pores as confirmed by TEM and X-ray diffraction measurements [13] in Table 14. The 
surface acidity measurements for all prepared MCM-41 catalysts are listed in Table 15.

The same trend in surface acidity variation observed with previous catalysts $\left(\mathrm{ZrO}_{2}, \mathrm{TiO}_{2}\right.$ and $\left.\mathrm{HfO}_{2}\right)$ was also repeated with the MCM-41 catalysts, but the difference here was that even when sulfated with $1 \mathrm{M} \mathrm{H}_{2} \mathrm{SO}_{4}$ aqueous solution the catalyst showed weak surface acidity.

\section{2) SBA-15 Catalysts}

SAB-15 ALH 39 and Nb-SBA-15 ALH 40, showed typical hexagonal arrangement of pores confirmed by TEM and X-ray diffraction [13] in Table 16. The surface acidity measurements for all prepared SBA-15 catalysts are listed in Table 17.

The surface acidity measurements observed with MCM- 41 catalysts was also observed with SBA-15 catalysts. These surface acidity measurements observed throughout all prepared catalysts were in correlation with the catalytic activity of these catalysts in the etherification reaction of 2-naphtol.

\subsection{Catalytic Evaluations}

\subsubsection{Catalytic Evaluation of Zirconium Catalysts}

1) Catalytic Evaluation of Zirconium Catalysts Prepared by the Precipitation Method

Table 14. MCM-41 and Nb-MCM-41 physical properties.

\begin{tabular}{cccc}
\hline $\begin{array}{c}\text { Catalyst } \\
\text { code }\end{array}$ & $\begin{array}{c}\text { Catalyst } \\
\text { composition }\end{array}$ & $\begin{array}{c}\text { BET surface } \\
\text { area }\left(\mathrm{m}^{2} / \mathrm{g}\right)\end{array}$ & $\begin{array}{c}\text { Nature } \\
\text { of phase }\end{array}$ \\
\hline ALH 33 & MCM-41 & 1090 & hexagonal arrangement of pores \\
ALH 34 & Nb-MCM-41 & 1050 & hexagonal arrangement of pores \\
\hline
\end{tabular}

Table 15. Acidity measurements of MCM-41 catalysts prepared by templated sol-gel method.

\begin{tabular}{|c|c|c|}
\hline $\begin{array}{l}\text { Catalyst } \\
\text { code }\end{array}$ & $\begin{array}{c}\text { Catalyst } \\
\text { composition }\end{array}$ & $\begin{array}{c}\text { Acidity } \\
\mathrm{n}^{\mathrm{H}+}(\mathrm{mmol} / \mathrm{g})\end{array}$ \\
\hline ALH 33 & MCM-41 & 0.7 \\
\hline ALH 34 & Nb-MCM-41 & 1.7 \\
\hline ALH 35 & $\mathrm{MCM}-41 / \mathrm{SO}_{4}^{2-} \quad(0.5 \mathrm{M})$ & 5.3 \\
\hline ALH 36 & $\mathrm{MCM}-41 / \mathrm{SO}_{4}^{2-} \quad(1 \mathrm{M})$ & 5.9 \\
\hline ALH 37 & MCM-41/Nb (3\%) & 2 \\
\hline ALH 38 & MCM-41/Nb (5\%) & 2.1 \\
\hline
\end{tabular}

Table 16. SBA-15 and Nb-SBA-15 physical properties.

\begin{tabular}{cccc}
$\begin{array}{c}\text { Catalyst } \\
\text { code }\end{array}$ & $\begin{array}{c}\text { Catalyst } \\
\text { composition }\end{array}$ & $\begin{array}{c}\text { BET surface } \\
\text { area }\left(\mathrm{m}^{2} / \mathrm{g}\right)\end{array}$ & $\begin{array}{c}\text { Nature } \\
\text { of phase }\end{array}$ \\
\hline ALH 39 & SBA-15 & 790 & $\begin{array}{c}\text { hexagonal arrangement of pores } \\
\text { hexagonal arrangement of pores }\end{array}$ \\
ALH 40 & Nb-SBA-15 & 660 & hem \\
\hline
\end{tabular}


Table 17. Acidity measurements of SBA-15 catalysts prepared by templated sol-gel method.

\begin{tabular}{ccc}
\hline $\begin{array}{c}\text { Catalyst } \\
\text { code }\end{array}$ & $\begin{array}{c}\text { Catalyst } \\
\text { composition }\end{array}$ & $\begin{array}{c}\text { Acidity } \\
\mathbf{n}^{\mathrm{H+}}(\mathbf{m m o l} / \mathbf{g})\end{array}$ \\
\hline $\mathrm{ALH} 39$ & $\mathrm{SBA}-15$ & 0.9 \\
$\mathrm{ALH} 40$ & $\mathrm{Nb}-\mathrm{SBA}-15$ & 1.5 \\
$\mathrm{ALH} 41$ & $\mathrm{SBA}-15 / \mathrm{SO}_{4}^{2-}(0.5 \mathrm{M})$ & 5.7 \\
$\mathrm{ALH} 42$ & $\mathrm{SBA}^{-15} / \mathrm{SO}_{4}^{2-} \quad(1 \mathrm{M})$ & 6 \\
$\mathrm{ALH} 43$ & $\mathrm{SBA}-15 / \mathrm{Nb}(3 \%)$ & 2.1 \\
$\mathrm{ALH} 44$ & $\mathrm{SBA}-15 / \mathrm{Nb}(5 \%)$ & 2.1 \\
\hline
\end{tabular}

Zirconium catalysts prepared by the precipitation method were tested in the etherification of 2-naphtol with butanol. The obtained results are shown in Table 18.

Zircon zirconium catalysts $\mathrm{ZrO}_{2}$ were unreactive. This is not surprising since that zirconium oxide itself has very low acidity on its surface, our acidity measurements confirmed this observation $\left(1.5 \mathrm{mmol} \mathrm{H} \mathrm{H}^{+} / \mathrm{g}\right)$. When sulfated, it showed moderate catalytic activity towards butoxynaphtalene (2) formation, this revealed an acidic character gained after sulfating, which was expected since sulfated zirconium oxide has a strong surface acidity $\left(8 \mathrm{mmol} \mathrm{H}^{+} / \mathrm{g}\right)$. Even when sulfated with a higher concentration of sulfuric acid during impregnation which showed slightly higher surface acidity $\left(9 \mathrm{mmol} \mathrm{H}^{+} / \mathrm{g}\right)$, it showed a very small increase in the yield of butoxynaphtalene (2). On the other hand when the zirconium oxide was impregnated with niobium, it showed redox properties and weak acidity $\left(3 \mathrm{mmol} \mathrm{H} \mathrm{H}^{+} / \mathrm{g}\right)$, even if very small conversions were obtained but the products formed (3), (4) and (5) were a clear evidence of these redox catalytic properties. The proposed mechanisms for the formation of these products will be discussed later.

The acidity of supported niobium oxides has been previously investigated [15] and showed that mostly Lewis acid sites were detected on supports like (silica, magnesia, Titania and zirconia), and that Brönsted acidity was only detected when niobium was supported on alumina or silica. Another study [16] showed that Brönsted acid sites appeared also on zirconia supports doped with niobium.

In our particular reaction even though the formation of butoxynaphtalene (2) requires Brönsted acid sites instead of Lewis acid sites, it appears that the Brönsted acid sites on our prepared $\mathrm{ZrO}_{2} / \mathrm{Nb}$ weren't strong enough to catalyze the reaction, instead this catalyst showed a redox character.

2) Catalytic Evaluation of Zirconium Catalysts Prepared by the Sol-Gel Method

The etherification reaction of 2-naphtol was tested with zirconium oxide catalysts prepared by the sol-gel method, either in basic medium or acid medium. The obtained results are shown in Table 19.

If we compare all these results with the previous ones obtained with 
Table 18. Catalytic evaluation of zirconium catalysts prepared by precipitation method.

\begin{tabular}{cccccccc}
\hline \multirow{2}{*}{ Entry } & \multirow{2}{*}{$\begin{array}{c}\text { Catalyst } \\
\text { code }\end{array}$} & $\begin{array}{c}\text { Catalyst } \\
\text { composition }\end{array}$ & $\begin{array}{c}\text { Conversion } \\
\%\end{array}$ & & \multicolumn{4}{c}{ Product yield (\%) } \\
\cline { 6 - 8 } & $\mathrm{ALH} \mathrm{94}$ & $\mathrm{ZrO}_{2}$ & - & - & - & - & - \\
\hline 1 & $\mathrm{ALH} \mathrm{94} \mathrm{(1)}$ & $\mathrm{ZrO}_{2} / \mathrm{SO}_{4}^{2-}(0.5 \mathrm{M})$ & 32 & 25 & - & - & - \\
3 & $\mathrm{ALH} \mathrm{94} \mathrm{(2)}$ & $\mathrm{ZrO}_{2} / \mathrm{SO}_{4}^{2-}(1 \mathrm{M})$ & 34 & 28 & - & - & - \\
4 & $\mathrm{ALH} \mathrm{94} \mathrm{(3)}$ & $\mathrm{ZrO}_{2} / \mathrm{Nb}(3 \%)$ & $5>$ & - & traces & traces & traces \\
5 & ALH 94 (4) & $\mathrm{ZrO}_{2} / \mathrm{Nb}(5 \%)$ & $5>$ & - & traces & traces & traces \\
\hline
\end{tabular}

Table 19. Catalytic evaluation of zirconium catalysts prepared by sol-gel method.

\begin{tabular}{|c|c|c|c|c|c|c|c|}
\hline \multirow{2}{*}{ Entry } & \multirow{2}{*}{$\begin{array}{l}\text { Catalyst } \\
\text { code }\end{array}$} & \multirow{2}{*}{$\begin{array}{c}\text { Catalyst } \\
\text { composition }\end{array}$} & \multirow{2}{*}{$\begin{array}{c}\text { Conversion } \\
\%\end{array}$} & \multicolumn{4}{|c|}{ Product yield (\%) } \\
\hline & & & & (2) & (3) & (4) & (5) \\
\hline 1 & ALH 6 & $\mathrm{ZrO}_{2}$ & - & - & - & - & - \\
\hline 2 & ALH 7 & $\mathrm{ZrO}_{2} / \mathrm{SO}_{4}^{2-} \quad(0.5 \mathrm{M})$ & 34 & 28 & - & - & - \\
\hline 3 & ALH 8 & $\mathrm{ZrO}_{2} / \mathrm{SO}_{4}^{2-} \quad(1 \mathrm{M})$ & 36 & 30 & & & \\
\hline 4 & ALH 9 & $\mathrm{ZrO}_{2} / \mathrm{Nb}(3 \%)$ & $5>$ & - & traces & traces & traces \\
\hline 5 & ALH 10 & $\mathrm{ZrO}_{2} / \mathrm{Nb}(5 \%)$ & $5>$ & - & traces & traces & traces \\
\hline 6 & ALH 11 & $\mathrm{ZrO}_{2}-\mathrm{SO}_{4}^{2-}$ & 40 & 35 & - & - & - \\
\hline
\end{tabular}

zirconium oxides prepared by the precipitation method, we will find almost the same general catalytic activity, but with the zirconium catalysts prepared by the sol-gel method we can see a slight increase in catalytic activity, with small increase in butoxynaphtalene (2) yields. So the sol-gel method is a more efficient way to give more active catalysts. However when the zirconium oxide is in-situ sulfated (ALH $11 \quad \mathrm{ZrO}_{2}-\mathrm{SO}_{4}^{2-}$ ) higher yields of butoxynaphtalene (2) were obtained, as surface acidity is higher, this showed that in-situ sulfating gives rise to better acidity which translates into higher catalytic activity.

The catalytic activity observed in both cases showed that when sulfated the zirconium oxide showed acidic properties and when impregnated with niobium it showed both redox and weak acidic properties.

\subsubsection{Catalytic Evaluation of Titanium Catalysts}

1) Catalytic Evaluation of Titanium Catalysts Prepared by the Precipitation Method

The etherification reaction of 2-naphtol was tested with titanium oxide catalysts prepared by the precipitation method. The obtained results are shown in Table 20.

Titanium catalysts prepared by precipitation method, showed similar yet weaker catalytic activity compared to all zirconium catalysts (lower 2-naphtol conversions and product yields), this is probably caused by weaker acidity of titanium catalysts in Tables 10-12 compared to zirconium catalysts in Table 8 and Table 9. Even if titanium catalysts ALH 12 have higher surface area $104 \mathrm{~m}^{2} / \mathrm{g}$ than 
Table 20. Catalytic evaluation of titanium catalysts prepared by precipitation method.

\begin{tabular}{|c|c|c|c|c|c|c|c|}
\hline \multirow{2}{*}{ Entry } & \multirow{2}{*}{$\begin{array}{l}\text { Catalyst } \\
\text { code }\end{array}$} & \multirow{2}{*}{$\begin{array}{c}\text { Catalyst } \\
\text { composition }\end{array}$} & \multirow{2}{*}{$\begin{array}{c}\text { Conversion } \\
\%\end{array}$} & \multicolumn{4}{|c|}{ Product yield (\%) } \\
\hline & & & & (2) & (3) & (4) & (5) \\
\hline 1 & ALH 12 & $\mathrm{TiO}_{2}$ & - & - & - & - & - \\
\hline 2 & ALH 13 & $\begin{array}{c}\mathrm{TiO}_{2} / \mathrm{SO}_{4}^{2-} \quad(0.5 \\
\mathrm{M})\end{array}$ & 16 & 9 & - & - & - \\
\hline 3 & ALH 14 & $\mathrm{TiO}_{2} / \mathrm{SO}_{4}^{2-} \quad(1 \mathrm{M})$ & 18 & 15 & - & - & - \\
\hline 4 & ALH 15 & $\mathrm{TiO}_{2} / \mathrm{Nb}(3 \%)$ & $5>$ & traces & traces & traces & traces \\
\hline 5 & ALH 16 & $\mathrm{TiO}_{2} / \mathrm{Nb}(5 \%)$ & $5>$ & traces & traces & traces & traces \\
\hline
\end{tabular}

zirconium catalyst ALH $365.3 \mathrm{~m}^{2} / \mathrm{g}$, this does not mean that titanium catalysts should have given higher catalytic activity, the probable determining factor was the higher surface acidity.

The same research group that studied the surface acidity of $\mathrm{ZrO}_{2} / \mathrm{NbO}_{\mathrm{x}}$ catalytic systems, also studied [17] [18] the $\mathrm{TiO}_{2} / \mathrm{NbO}_{\mathrm{x}}$ and concluded that the results obtained with both systems indicate a direct relation between the abundance of Brönsted acid sites and the formation of polymeric $\mathrm{NbO}_{\mathrm{x}}$ species. But $\mathrm{TiO}_{2} / \mathrm{NbO}_{\mathrm{x}}$ system showed that the development of Brönsted acidity as a function of $\mathrm{Nb}$ loading is different from that observed for the $\mathrm{ZrO}_{2} / \mathrm{NbO}_{\mathrm{x}}$ system. In our tested reaction (etherification of 2-naphtol) these Brönsted acid sites on $\mathrm{TiO}_{2} / \mathrm{NbO}_{\mathrm{x}}$ gave traces of butoxynaphtalene (2) which indicated a slightly higher acidity than the $\mathrm{ZrO}_{2} / \mathrm{NbO}_{\mathrm{x}}$ that did not yield the aromatic ether at all.

2) Catalytic Evaluations of Titanium Catalysts Prepared by the Sol-Gel Method

Titanium oxide catalysts prepared by the sol-gel method were tested with the etherification reaction of 2-naphtol. The obtained results are shown in Table 21.

Titanium catalysts prepared by the sol-gel method, showed similar catalytic activity compared to previous catalysts tested: when oxide is sulfated low conversions of 2-naphtol (1) and low yields of butoxynaphtalene (2); when oxide is impregnated with niobium, redox properties were observed. The in-situ sulfated titanium oxide showed small increase in conversion of 2-naphtol (1) and better yields of butoxynaphtalene (2), this indicates that in-situ sulfating gave the catalysts with better activity due to higher surface acidity.

Titanium catalysts prepared by the sol-gel method showed slightly higher catalytic activity than titanium catalysts prepared by the precipitation method, probably due to its higher surface area (Section 3.2.2).

3) Catalytic Evaluations of Titanium Catalysts Prepared by the Templated Sol-Gel Method

Titanium oxides prepared by the templated sol-gel method were tested with the etherification reaction of 2-naphtol. The obtained results are shown in Table 22.

Titanium oxides prepared by the templated sol-gel method gave catalysts with slightly higher but similar activity compared to other titanium catalysts, this is 
Table 21. Catalytic evaluation of titanium catalysts prepared by sol-gel method.

\begin{tabular}{cccccccc}
\hline \multirow{2}{*}{ Entry } & \multirow{2}{*}{$\begin{array}{c}\text { Catalyst } \\
\text { code }\end{array}$} & $\begin{array}{c}\text { Catalyst } \\
\text { composition }\end{array}$ & $\begin{array}{c}\text { Conversion } \\
\%\end{array}$ & \multicolumn{5}{c}{ Product yield (\%) } \\
\cline { 6 - 8 } 1 & $\mathrm{ALH} 17$ & $\mathrm{TiO}_{2}$ & - & - & - & - & - \\
2 & $\mathrm{ALH} \mathrm{18}$ & $\mathrm{TiO}_{2}-\mathrm{SO}_{4}^{2-}(1 \mathrm{M})$ & 25 & 21 & - & - & - \\
3 & $\mathrm{ALH} \mathrm{19}$ & $\mathrm{TiO}_{2} / \mathrm{SO}_{4}^{2-}(0.5$ & 20 & 18 & - & - & - \\
4 & $\mathrm{ALH} \mathrm{20}$ & $\mathrm{TiO}_{2} / \mathrm{SO}_{4}^{2-} \quad(1 \mathrm{M})$ & 20 & 17 & - & - & - \\
5 & $\mathrm{ALH} \mathrm{21}$ & $\mathrm{TiO}_{2} / \mathrm{Nb}(3 \%)$ & $5>$ & traces & traces & traces & traces \\
6 & $\mathrm{ALH} \mathrm{22}$ & $\mathrm{TiO}_{2} / \mathrm{Nb}(5 \%)$ & $5>$ & traces & traces & traces & traces
\end{tabular}

Table 22. Catalytic evaluation of titanium catalysts prepared by templated sol-gel method.

\begin{tabular}{cccccccc}
\hline \multirow{2}{*}{ Entry } & \multirow{2}{*}{$\begin{array}{c}\text { Catalyst } \\
\text { code }\end{array}$} & $\begin{array}{c}\text { Catalyst } \\
\text { composition }\end{array}$ & $\begin{array}{c}\text { Conversion } \\
\%\end{array}$ & \multicolumn{5}{c}{ Product yield (\%) } \\
\cline { 6 - 8 } & $\mathrm{ALH} \mathrm{23}$ & $\mathrm{TiO}_{2}$ & - & - & - & - & - \\
\hline 1 & $\mathrm{ALH} 24$ & $\mathrm{TiO}_{2} / \mathrm{SO}_{4}^{2-}(0.5 \mathrm{M})$ & 26 & 20 & - & - & - \\
2 & $\mathrm{ALH} 25$ & $\mathrm{TiO}_{2} / \mathrm{SO}_{4}^{2-}(1 \mathrm{M})$ & 30 & 26 & - & - & - \\
3 & $\mathrm{ALH} \mathrm{26}$ & $\mathrm{TiO}_{2} / \mathrm{Nb}(3 \%)$ & $5>$ & traces & traces & traces & traces \\
4 & $\mathrm{ALH} \mathrm{27}$ & $\mathrm{TiO}_{2} / \mathrm{Nb}(5 \%)$ & $5>$ & traces & traces & traces & traces \\
\hline
\end{tabular}

due to higher surface area of ALH $23\left(250 \mathrm{~m}^{2} / \mathrm{g}\right)$ compared to ALH $18(142.8$ $\left.\mathrm{m}^{2} / \mathrm{g}\right)$ and ALH $13\left(104 \mathrm{~m}^{2} / \mathrm{g}\right)$. The determining factor that gave the catalyst with improved activity was the surface area not surface acidity.

\subsubsection{Catalytic Evaluation of Hafnium Catalysts}

Hafnium oxides prepared by precipitation method were tested with the etherification reaction of 2-naphtol (1). The obtained results are shown in Table 23.

With hafnium oxides, a similar but much higher activity was observed than previous catalysts tested $\left(\mathrm{ZrO}_{2}\right.$ and $\left.\mathrm{TiO}_{2}\right)$, higher yields of butoxynaphtalene (2) when oxide is sulfated. This is due to the higher surface acidity of sulfated hafnium in Table 13. When impregnated with niobium a redox character was also observed, this time with traces of butoxynaphtalene (2) formed showing a weak acidic character confirmed by the low surface acidity measurements.

\subsubsection{Catalytic Evaluation of Meso-structured Silicon Oxide Based Catalysts \\ 1) Catalytic Evaluation of MCM-41 Catalysts}

MCM-41 catalysts were tested with the etherification reaction of 2-naphtol (1). The obtained results are shown in Table 24.

MCM-41 catalysts showed different catalytic activity than previous catalysts tested $\left(\mathrm{ZrO}_{2}, \mathrm{TiO}_{2}\right.$ and $\left.\mathrm{HfO}_{2}\right)$. The bare MCM-41 showed no catalytic activity. When sulfated the MCM-41 support had very weak surface acidity compared to 
Table 23. Catalytic evaluation of Hafnium catalysts prepared by precipitation method.

\begin{tabular}{cccccccc}
\hline & \multirow{2}{*}{$\begin{array}{c}\text { Catalyst } \\
\text { code }\end{array}$} & $\begin{array}{c}\text { Catalyst } \\
\text { composition }\end{array}$ & $\begin{array}{c}\text { Conversion } \\
\%\end{array}$ & \multicolumn{5}{c}{ Product yield (\%) } \\
\cline { 5 - 8 } & & & & $(2)$ & $(3)$ & $(4)$ & $(5)$ \\
\hline 1 & $\mathrm{ALH} \mathrm{28}$ & $\mathrm{HfO}_{2}$ & $5>$ & traces & - & - & - \\
2 & $\mathrm{ALH} \mathrm{29}$ & $\mathrm{HfO}_{2} / \mathrm{SO}_{4}^{2-}(0.5 \mathrm{M})$ & 60 & 55 & - & - & - \\
3 & $\mathrm{ALH} \mathrm{30}$ & $\mathrm{HfO}_{2} / \mathrm{SO}_{4}^{2-}(1 \mathrm{M})$ & 70 & 62 & - & - & - \\
4 & $\mathrm{ALH} \mathrm{31}$ & $\mathrm{HfO}_{2} / \mathrm{Nb}(3 \%)$ & $5>$ & traces & traces & traces & traces \\
5 & $\mathrm{ALH} \mathrm{32}$ & $\mathrm{HfO}_{2} / \mathrm{Nb}(5 \%)$ & $5>$ & traces & traces & traces & traces \\
\hline
\end{tabular}

Table 24. Catalytic evaluation of MCM-41 catalysts prepared by templated sol-gel method.

\begin{tabular}{|c|c|c|c|c|c|c|c|}
\hline \multirow{2}{*}{ Entry } & \multirow{2}{*}{$\begin{array}{l}\text { Catalyst } \\
\text { code }\end{array}$} & \multirow{2}{*}{$\begin{array}{c}\text { Catalyst } \\
\text { composition }\end{array}$} & \multirow{2}{*}{$\begin{array}{c}\text { Conversion } \\
\%\end{array}$} & \multicolumn{4}{|c|}{ Product yield (\%) } \\
\hline & & & & (2) & (3) & (4) & (5) \\
\hline 1 & ALH 33 & MCM-41 & - & - & - & - & - \\
\hline 2 & ALH 34 & Nb-MCM-41 & 45 & traces & 7 & 13 & 23 \\
\hline 3 & ALH 35 & $\mathrm{MCM}-41 / \mathrm{SO}_{4}^{2-} \quad(0.5 \mathrm{M})$ & 15 & 12 & - & - & - \\
\hline 4 & ALH 36 & $\mathrm{MCM}-41 / \mathrm{SO}_{4}^{2-} \quad(1 \mathrm{M})$ & 18 & 16 & - & - & - \\
\hline 5 & ALH 37 & $\mathrm{MCM}-41 / \mathrm{Nb}(3 \%)$ & 35 & traces & 6 & 10 & 19 \\
\hline 6 & ALH 38 & MCM-41/Nb (5\%) & 36 & traces & 8 & 9 & 16 \\
\hline
\end{tabular}

previous sulfated oxides $\left(\mathrm{ZrO}_{2}, \mathrm{TiO}_{2}\right.$ and $\left.\mathrm{HfO}_{2}\right)$, which explains the relative low conversion of 2-naphtol and low yields of butoxynaphtalene. But better redox properties were obtained when MCM-41 was impregnated with niobium especially when in-situ impregnated. This superior redox character could be attributed to the much higher surface area and bigger pore volume of meso-structured materials than normal porous oxides.

\section{2) Catalytic Evaluation of SBA-15 Catalysts}

SBA-15 catalysts were tested with the etherification reaction of 2-naphtol (1). The obtained results are shown in Table 25 .

SBA-15 catalysts showed similar catalytic activity to MCM-41 catalysts. The superior redox properties of Nb-SBA- 15 compared to Nb-MCM-41 could be attributed to its higher hydrothermal stability [19], even if the SBA-15 support has smaller surface area compared to MCM- 41 .

\subsection{Proposed Mechanisms for Products Resulting from the Etherification Reaction of 2-Naphtol}

In the etherification reaction of 2-naphtol, the expected product was 2-butoxynaphtalene (2), this reaction was used to evaluate surface acidity strength of the catalyst. But after the initial screening tests of our catalysts, clear redox character was observed alongside their intended acidic nature and the surprising products 
Table 25. Catalytic evaluation of SBA-15 catalysts prepared by templated sol-gel method.

\begin{tabular}{|c|c|c|c|c|c|c|c|}
\hline \multirow{2}{*}{ Entry } & \multirow{2}{*}{$\begin{array}{l}\text { Catalyst } \\
\text { code }\end{array}$} & \multirow{2}{*}{$\begin{array}{c}\text { Catalyst } \\
\text { composition }\end{array}$} & \multirow{2}{*}{$\begin{array}{c}\text { Conversion } \\
\%\end{array}$} & \multicolumn{4}{|c|}{ Product yield (\%) } \\
\hline & & & & (2) & (3) & $(4)$ & (5) \\
\hline 1 & ALH 39 & SBA-15 & - & - & - & - & - \\
\hline 2 & ALH 40 & Nb-SBA-15 & 58 & traces & 10 & 17 & 28 \\
\hline 3 & ALH 41 & SBA-15/ $\mathrm{SO}_{4}^{2-} \quad(0.5 \mathrm{M})$ & 18 & 15 & - & - & - \\
\hline 4 & ALH 42 & SBA-15/ $\mathrm{SO}_{4}^{2-} \quad(1 \mathrm{M})$ & 17 & 16 & - & - & - \\
\hline 5 & ALH 43 & SBA-15/Nb (3\%) & 41 & traces & 7 & 11 & 22 \\
\hline 6 & ALH 44 & SBA-15/Nb (5\%) & 42 & traces & 8 & 12 & 20 \\
\hline
\end{tabular}

formed that were not expected; furan (4), acetal (3) and binol (5). It was interesting for us to understand the mechanism pathways responsible for the formation of these products.

\subsubsection{Proposed Mechanism for Binol (4) Formation}

Previous studies [14] [20] were done on the formation of binol (4) through the oxidative coupling of 2-naphtol, although the mechanism is still not fully understood, the procedure itself appear to be a potential new methodology for catalytic asymmetric $\mathrm{C}-\mathrm{C}$ bond formation triggered by an electron-transfer process. In our work, binol formation from 2-naphtol was observed when transition metal niobium was impregnated on mesoporous siliceous materials (SBA-15 and MCM-41), although the catalysts tested had poor conversions and low chemical yields for binol, still it was interesting. We believe that in our case the binol formation proceeded through a radical mechanism in Scheme 2, since peroxide tests (using Peroxide 25 test sticks) turned out positive indicating the presence of peroxide intermediates in the reaction medium. This mechanism was also proposed previously [21], where oxidation reactions carried out on 2-naphtol in presence of $\mathrm{H}_{2} \mathrm{O}_{2}$ and a catalyst (crystalline vanadium phosphates) gave binol as a secondary product. In their proposed mechanism the hydroxyl radicals are generated from the hydrogen peroxide used in the reaction, but in our case we believe that the hydroxyl radicals species could be generated from the molecular oxygen $\left(\mathrm{O}_{2}\right)$ in ambient air, since our etherification reactions were carried out in open air, and what enforced this proposal was our observations that when we attempted to reproduce this reaction under nitrogen atmosphere nothing happened and no conversion of 2-naphtol was observed in Scheme 3.

\subsubsection{Proposed Mechanism for 2-Butoxynaphtalene (2) Formation}

In previous work [14] a mechanism for the etherification of 2-naphtol to butoxynaphtalene (2) was proposed in Scheme 4. In this mechanism it is suggested that the 2-naphtol takes the role of an electrophile while the alcohol takes the role of a nucleophile.

In our case, with the sulfated oxides $\left(\mathrm{ZrO}_{2}, \mathrm{TiO}_{2}, \mathrm{HfO}_{2}, \mathrm{MCM}-41\right.$ and SBA-15) a proton is generated in the reaction medium, since our catalysts possess surface 


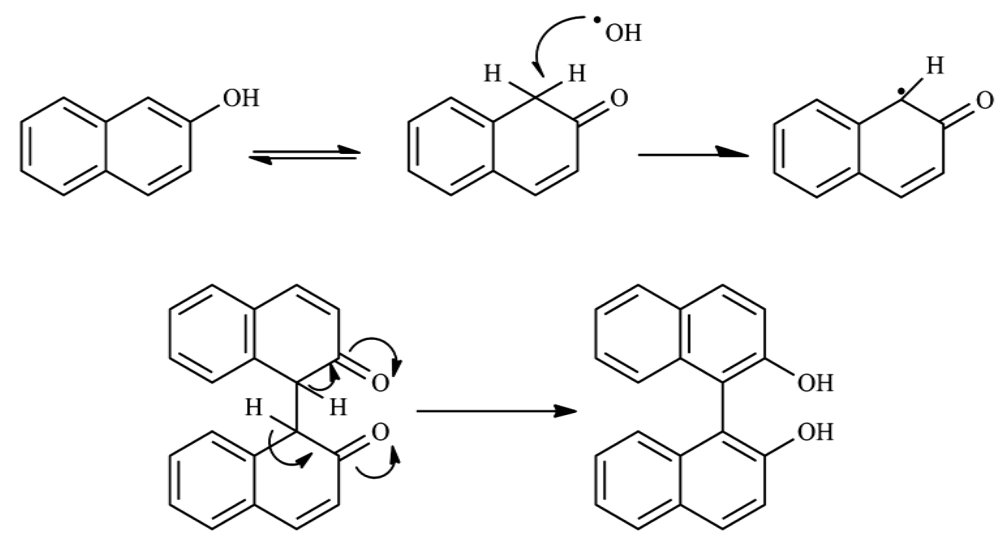

Scheme 2. Mechanism for Binol formation.

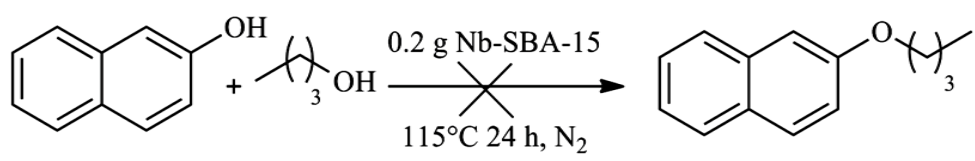

Scheme 3. Etherification of 2-naphtol done under nitrogen atmosphere.

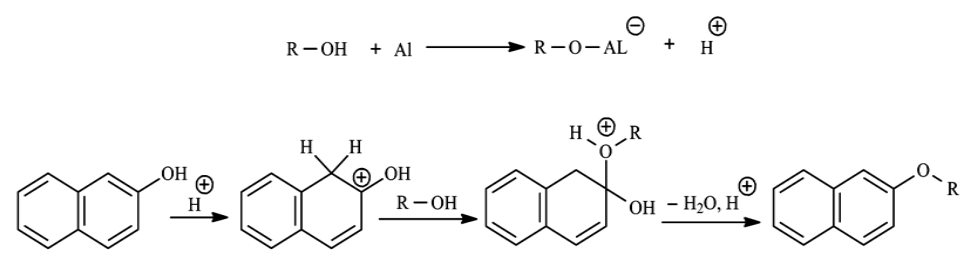

Scheme 4. Etherification of 2-naphtol by acid catalysis.

Brönsted acid sites. This proton then reacts with 2-naphtol to give a carbocation, which in turn is attacked by the alcohol (butanol in our case). Next an elimination of a water molecule takes place and finally a re-aromatization yields the desired ether.

\subsubsection{Proposed Mechanism for Acetal of Binol (3) Formation}

In each etherification reaction of 2-naphtol that yielded amongst its products the acetal of binol, a very small trace of the aldehyde (butanal) was detected in the reaction medium, confirmed in the ${ }^{1} \mathrm{H}$ NMR of the crude after reaction completion, by a characteristic triplet at $9.7 \mathrm{ppm}$. This aldehyde (butanal) was formed by the oxidation or dehydrogenation of butanol.

Knowing that an aldehyde (butanal) is formed in the reaction medium with the presence of binol under acidic conditions provided by our catalysts through their Brönsted acid sites, we can propose the following mechanism for the acetal formation in Scheme 5.

\subsubsection{Proposed Mechanism for Naphtofuran (4) Formation}

Attempts were made to understand how the naphtofuran (4) was formed. First a pure sample of butoxynaphtalene (2) was synthesized separately using a preparation method taken from the literature [14] in Scheme 6. 


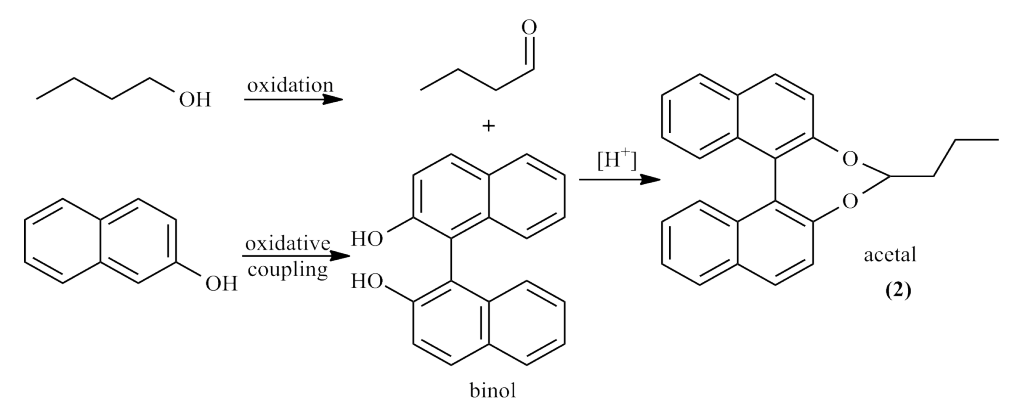

Scheme 5. Proposed pathway for acetal of binol formation.

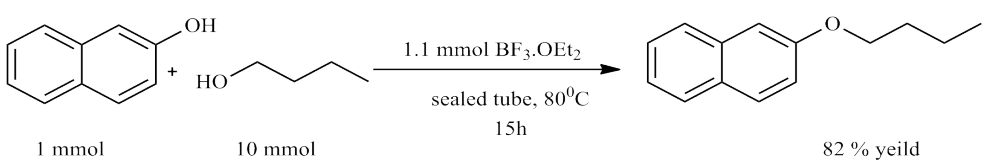

Scheme 6. Preparation of butoxynaphtalene using boron trifluoride as a catalytic system.

\section{The following experimental procedure was used:}

To a solution of 2-naphthol (144 mg, $1 \mathrm{mmol})$ in Butanol $(750 \mathrm{ml}, 10 \mathrm{mmol})$ was added boron trifluoride ( $48 \%$ in ether, $300 \mathrm{ml}, 1.1 \mathrm{mmol}$ ). The tube was sealed and the mixture was stirred at $80^{\circ} \mathrm{C}$ during 15 hours. The mixture was quenched with water $(10 \mathrm{ml})$ and extracted three times with dichloromethane (3 $\times 5 \mathrm{ml})$. The combined organic layers were washed with brine $(10 \mathrm{ml})$, dried over $\mathrm{MgSO}_{4}$ and concentrated. The crude was purified by column chromatography (cyclohexane/ethyl acetate: 9/1) to afford the 2-butoxy naphthalene ( $82 \%$ yield) as yellow oil.

This prepared pure sample of butoxynaphtalene was then reacted with the catalyst that showed the highest redox activity (Nb-SBA-15 ALH 40) in the same reaction condition described previously (Section 2.5). No reaction took place, showing that the butoxynaphtalene did not transform into the furan in Scheme 7.

In another attempt the 2-naphtol was reacted with butanal instead of butanol in Scheme 8, under the same reaction conditions 2 products (furan and binol) were obtained, so the only mechanism that we could think of is illustrated in Scheme 9.

\section{Conclusions}

Our prepared catalysts tested in the etherification reaction of 2-naphtol have shown 2 different catalytic properties: first an acidic character, and second a redox character.

The acidic character was observed when oxides $\left(\mathrm{ZrO}_{2}, \mathrm{TiO}_{2}, \mathrm{HfO}_{2}\right)$ and mesoporous siliceous materials (MCM-41 and SBA-15) were impregnated with sulfate ions. This acidity was induced from sulfate ions impregnated on the surface of the solids using sulfuric acid as precursor, this method proved that the amount of surface acidity (measured in $\mathrm{mmol} \mathrm{H}^{+} / \mathrm{g}$ ) increased with the concentration of sulfuric acid used during impregnation to an optimal concentration of 


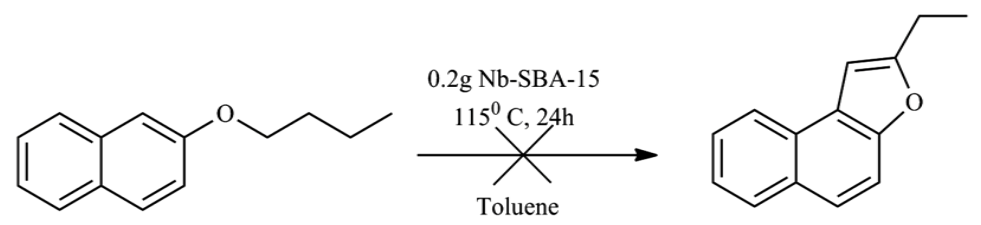

Scheme 7. Reaction of butoxynaphtalene with Nb-SBA-15.

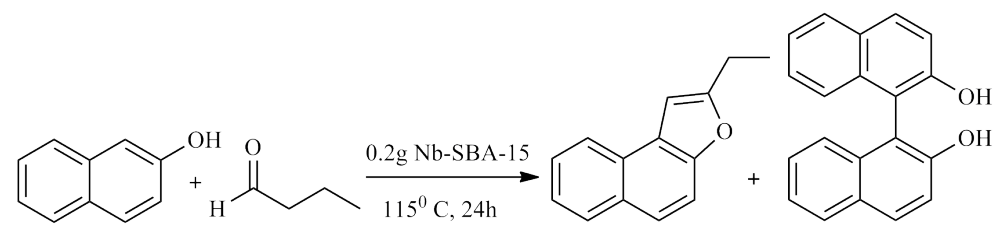

Scheme 8. Reaction between 2-naphtol and butanal.

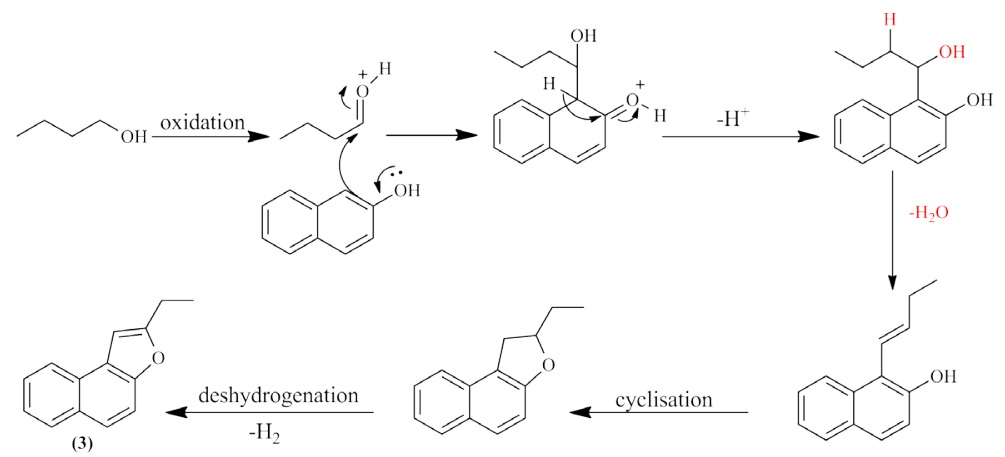

Scheme 9. Proposed mechanism for naphtofuran formation.

$1 \mathrm{M}$. In addition, in-situ sulfating gave higher acidity than post impregnation method. These sulfated oxides although acidic in nature, had very weak catalytic activity towards converting 2-naphtol into butoxynaphtalene, a very well-known organic reaction catalyzed by conventional liquid acids.

On the other hand, when the oxides $\left(\mathrm{ZrO}_{2}, \mathrm{TiO}_{2}, \mathrm{HfO}_{2}\right)$ and mesoporous materials (MCM-41 and SBA-15) were impregnated with the transition metal niobium, a weak surface acidity was obtained that wasn't strong enough to catalyze the etherification of 2-naphtol into butoxynaphtalene. But these niobium doped catalysts showed interesting redox catalytic activity, where the formation of products resulting from oxidation of 2-naphtol (acetal of binol, naphtofuran and binol) were observed. A higher redox catalytic activity was observed with mesoporous materials (MCM-41 and SBA-15) compared to porous oxides, this is probably due to the much higher surface area of mesoporous materials compared to porous oxides. And in particular in-situ impregnated mesoporous materials with niobium showed the highest conversion rates of 2-naphtol. But unfortunately, all the niobium doped catalysts had very weak selectivity to form the most interesting product obtained (naphtofuran).

\section{Acknowledgements}

This work was funded by the Lebanese University (Lebanon) and Claude Ber- 
nard University (France) in the framework of the cooperative research program between these Universities. Preparation and characterization of the catalysts were done in EDST (Ecole Doctoral des Sciences et Technology-Liban) and catalytic tests were performed in CASYEN (CAtalysis, SYnthesis and Environment-France).

\section{References}

[1] Corma, A. (1997) From Microporous to Mesoporous Molecular Sieve Materials and their use in Catalysis. Chemical Reviews, 97, 2373-2419. https://doi.org/10.1021/cr960406n

[2] Reddy, B.M. and Patil, M.K. (2009) Organic Synthesis and Transformations Catalyzed by Sulfated Zirconia. Chemical Reviews, 109, 2185-2208. https://doi.org/10.1021/cr900008m

[3] Ullmann, F. (1903) New Mode of Diphenylamine Derivatives Formation. European Journal of Inorganic Chemistry, 36, 2382-2384. https://doi.org/10.1002/cber.190303602174

[4] Ullmann, F. and Engi, G. (1904) About 9-Diphenylxanthene. European Journal of Inorganic Chemistry, 37, 2367-2374. https://doi.org/10.1002/cber.190403702178

[5] Cazorla, C., Pfordt, E., Duclos, M.C., Metay, E. and Lemaire, M. (2011) $O$-Alkylation of Phenol Derivatives via a Nucleophilic Substitution. Green Chemistry, 13, 2482-2488. https://doi.org/10.1039/clgc15481h

[6] Ahmed, I., et al. (2013) Liquid-Phase Dehydration of Sorbitol to Isosorbide Using Sulfated Titania as a Solid Acid Catalyst. Chemical Engineering Science, 93, 91-95. https://doi.org/10.1016/j.ces.2013.01.068

[7] Eterigho, E.J., Lee, J.G.M. and Harvey, A.P. (2011) Triglyceride Cracking for Biofuel Production Using a Directly Synthesized Sulphated Zirconia Catalyst. Bioresource Technology, 102, 6313-6316. https://doi.org/10.1016/j.biortech.2011.02.040

[8] Mishra, M.K., Tyagi, B. and Jasra, R.V. (2004) Synthesis and Characterization of Nano-Crystalline Sulfated Zirconia by Sol-Gel Method. Journal of Molecular Catalysis A: Chemical, 223, 61-65. https://doi.org/10.1016/j.molcata.2003.09.040

[9] Jung, S.M. and Grange, P. (2001) Evidence of Correlation between Electronic Density and Surface Acidity of Sulfated $\mathrm{TiO}_{2}$. Catalysis Letters, 76, 27-30. https://doi.org/10.1023/A:1016764524365

[10] Krishnakumar, B., Velmurugan, R. and Swaminathan, M. (2011) $\mathrm{TiO}_{2}-\mathrm{SO}_{4}{ }^{2-}$ as a Novel Solid Acid Catalyst for Highly Efficient, Solvent Free and Easy Synthesis of Chalcones under Microwave Irradiation. Catalysis Communications, 12, 375-379. https://doi.org/10.1016/j.catcom.2010.10.015

[11] Meynen, V., Cool, P. and Vansant, E.F. (2009) Verified Syntheses of Mesoporous Materials. Microporous and Mesoporous Materials, 125, 170-223. https://doi.org/10.1016/j.micromeso.2009.03.046

[12] Ramadoss, A., Krishnamoorthy, K. and Kim, S.J. (2012) Novel Synthesis of Hafnium Oxide Nanoparticles by Precipitation Method and Its Characterization. Materials Research Bulletin, 47, 2680-2684. https://doi.org/10.1016/j.materresbull.2012.05.051

[13] Nowak, I. (2004) Textural and Structural Properties of Niobium-Containing Micro-, Meso- and Macroporous Molecular Sieves. Colloids and Surfaces A: Physico- 
chemical and Engineering Aspects, 241, 103-111.

https://doi.org/10.1016/j.colsurfa.2004.04.036

[14] Cazorla, C., (2011) O-Alkylation of Phenols Derivatives via a Nucleophilic Substitution. Ph.D. Thesis, universite Claude Bernard, Lyon.

[15] Datka, J., Turek, A.M., Jehng, J.M. and Wachs, I.E. (1992) Acidic Properties of Supported Niobium Oxide Catalysts: An Infrared Spectroscopy Investigation. Journal of Catalysis, 135, 186-199. https://doi.org/10.1016/0021-9517(92)90279-Q

[16] Onfroya, T., Cleta, G., Bukallahb, S.B., Herculesb, D.M. and Houallaa, M. (2003) Development of the Acidity of Zirconia-Supported Niobia Catalysts. Catalysis Letters, 89, 15-19. https://doi.org/10.1023/A:1024717505705

[17] Onfroy, T., et al. (2007) Surface Structure and Catalytic Performance of Niobium Oxides Supported on Titania. Applied Catalysis A: General, 316, 184-190. https://doi.org/10.1016/j.apcata.2006.09.021

[18] Onfroy, T., Clet, G., Bukallah, S.B., Visser, T. and Houalla, M. (2006) Acidity of Titania-Supported Tungsten or Niobium Oxide Catalysts Correlation with Catalytic Activity. Applied Catalysis A: General, 298, 80-87.

https://doi.org/10.1016/j.apcata.2005.09.021

[19] Zhang, F., et al. (2005) Understanding Effect of Wall Structure on the Hydrothermal Stability of Mesostructured Silica SBA-15. The Journal of Physical Chemistry $B$, 109, 8723-8732. https://doi.org/10.1021/jp044632+

[20] Hassan, J., Sevignon, M., Gozzi, C., Schulz, E. and Lemaire, M. (2002) Aryl-Aryl Bond Formation One Century after the Discovery of the Ullmann Reaction. Chemical Reviews, 102, 1359-1469. https://doi.org/10.1021/cr000664r

[21] Rocha, G.M.S.R.O., Johnstone, R.A.W. and Neves, M.G.P.M.S. (2002) Catalytic Effects of Metal(IV) Phosphates on the Oxidation of Phenol and 2-Naphthol. Journal of Molecular Catalysis A: Chemical, 187, 95-104. https://doi.org/10.1016/S1381-1169(02)00064-X 